\title{
Investor Communication and the Benefits of Cross-Listing \\ by
}

\author{
Nayana Reiter \\ A dissertation submitted in partial fulfillment \\ of the requirements for the degree of \\ Doctor of Philosophy \\ (Business Administration) \\ in the University of Michigan \\ 2017
}

Doctoral Committee:

Professor Gregory S. Miller, Chair

Assistant Professor Anna M. Costello

Associate Professor Jordan Siegel

Professor Linda L. Tesar

Associate Professor Christopher D. Williams 
nreiter@umich.edu

ORCID iD: 0000-0002-4998-6427

(C) Nayana Reiter 2017 


\section{ACKNOWLEDGMENTS}

I am grateful to the members of my dissertation committee for their invaluable guidance and support. In particular, I thank Greg Miller for teaching me how to be a better scholar. His mentorship has made this a thoughtful and rewarding journey. I thank Chris Williams for his constant willingness to provide feedback and for all of his support. I thank Anna Costello for her encouragement and guidance during my last year in the program. I also thank the other members of my dissertation committee, Jordan Siegel and Linda Tesar, for their helpful and constructive feedback on my dissertation.

Thanks also to all the Accounting Ph.D. students and faculty from the Ross School of Business who were an integral part of my experience as a Ph.D. student. In particular, I thank Ryan McDonough and Christina Synn for their friendship and for always being willing to help and give insightful suggestions.

I gratefully acknowledge financial support from the University of Michigan and the Paton Fellowship. I also thank Jairo Procianoy for believing in my potential and encouraging me to pursue a Ph.D. degree in the U.S.

Most importantly, I am grateful to my mother for her countless personal sacrifices and for being such a great example of strength and determination. Finally, my love and gratitude for my husband, Andre, for his unconditional love and support throughout the ups and downs of graduate school. 


\section{TABLE OF CONTENTS}

ACKNOWLEDGMENTS

LIST OF TABLES $\quad$ iii

ABSTRACT

CHAPTER

I. Introduction 1

II. Related Literature and Hypothesis Development 9

III. Sample and Variables 16

Sample and Descriptive Statistics 16

$\begin{array}{ll}\text { Variables } & 18\end{array}$

IV. Research Design and Findings 23

Relation between Communication and the Decline in Valuation Post Cross-Listing 23

Valuation and Liquidity of Cross-listed Firms and Investor Communication Choices in the Long Run $\quad 27$

Institutional, Media, and Analyst Following: Path Analysis 31

Investor Communication and Likelihood of Delisting 33

Cross-sectional Tests 33

Cultural Distance 34 
$\begin{array}{ll}\text { Language } & 34\end{array}$

Perceived Corruption 35

Legal Tradition 36

Level of Listing 36

Communication of Good and Bad News 38

Modeling the Decision to Communicate using Instrumental Variables 39

Communication with U.S. versus Local Investors 42

$\begin{array}{ll}\text { Falsification Tests } & 42\end{array}$

Initiation and Termination of Investor Communication Activities 43

Valuation Premium of Cross-listed Firms Relative to Non-cross-listed Firms 44

Product Market Benefits of Cross-Listing and Investor Communication 46

$\begin{array}{ll}\text { V. Conclusion } & 47\end{array}$

$\begin{array}{ll}\text { FIGURES } & 49\end{array}$

$\begin{array}{ll}\text { TABLES } & 51\end{array}$

$\begin{array}{lr}\text { APPENDIX } & 69\end{array}$

$\begin{array}{ll}\text { BIBLIOGRAPHY } & 73\end{array}$ 


\section{LIST OF TABLES}

Table 1 - Sample Selection $\quad 52$

Table 2 - Descriptive Statistics

Table 3 - Investor Communication Choices 56

Table 4 - Capital Market Benefits and Investor Communication Around Cross-Listing 58

Table 5 - Capital Market Benefits and Communication Choices of Cross-listed Firms in the $\begin{array}{ll}\text { Long Run } & 60\end{array}$

Table 6 - Cross-Sectional Tests

Table 7 - Instrumental Variables Regressions $\quad 64$

Table 8 - Communication with Local versus U.S. investors 66

Table 9 - Initiation and Termination of Investor Communication Activities and Capital $\begin{array}{ll}\text { Market Benefits } & 67\end{array}$

Table 10 - Valuation Premium of Cross-Listed Firms Relative to Non-Cross-Listed

$\begin{array}{ll}\text { Firms and Communication Choices } & 68\end{array}$ 


\begin{abstract}
A large body of literature finds that cross-listing is associated with capital market benefits. However, evidence also suggests that these benefits are mostly temporary. In this paper, I investigate whether communication with U.S. investors helps non-U.S. firms maintain the capital market benefits of U.S. listings. I find that investor communication mitigates the post cross-listing decline in valuation documented by prior studies. I also find that communication choices explain variation in the valuation, cost of capital and stock liquidity of cross-listed firms in the long run. These results are robust to concerns about potential self-selection bias and are stronger for firms from countries with lower corruption risk and fewer cultural differences from U.S. culture. Lastly, I compare the valuation of cross-listed and non-cross-listed firms. My findings suggest that a significant portion of the cross-listing valuation premium is associated with the investor communication practices of these firms. Firms that cross-list in the U.S. but do not communicate with U.S. investors are not valued at a premium relative to non-cross-listed firms from the same country. Overall, my results are consistent with investor communication being an important condition for firms to maintain the long-run benefits of cross-listing.
\end{abstract}




\section{CHAPTER I}

\section{Introduction}

Cross-listing shares abroad can reduce barriers to foreign investment, such as frictions to information flows and limited minority shareholder protection, resulting in capital market benefits for firms. Managers frequently state that they cross-list their firms' stock in order to achieve benefits such as greater foreign investor recognition, enhanced stock performance, and increased stock liquidity (Baker 1992; Mittoo 1992; Fanto and Karmel 1997). A large body of literature studies the consequences of international listings and finds that cross-listing is indeed associated with positive capital market outcomes. ${ }^{1}$ However, evidence also suggests that a significant portion of the capital market benefits of cross-listing is temporary, with corporate valuation falling sharply in the years after cross-listing (e.g., Foerster and Karolyi 1999; Gozzi, Levine, and Schmukler 2008). There is little consensus in the literature on whether cross-listing produces enduring benefits. In this paper, I investigate whether investor communication mitigates the sharp decline in valuation post cross-listing and whether it explains variation in cross-listed firms' valuation and liquidity in the long run after cross-listing.

While studies have sought to explain the time-series and cross-sectional variation in the benefits of cross-listing, little attention has been paid to the role of voluntary disclosure. Disclosure

\footnotetext{
${ }^{1}$ See Karolyi $(2006,2012)$ for a review of the literature on cross-listings.
} 
by management can decrease information asymmetry and mitigate international visibility issues, increasing stock liquidity and market valuation (e.g., Diamond and Verrecchia 1991; Easley and O'Hara 2004). In this paper, I address a gap in the literature and focus on the relation between the benefits of cross-listing and four channels of management-investor communication, namely corporate access events, conference calls, press releases, and management forecasts.

Prior literature suggests two main explanations for the capital market outcomes of crosslisting: increased investor recognition associated with a broader shareholder base (the investor recognition hypothesis) and better investor protection (the bonding hypothesis). Both explanations are related to improvements in the information environment of firms. I argue that foreign firms that do not meet the expectations of U.S. investors and analysts regarding the frequency and form of corporate communication may not be able to keep the long-run benefits of a U.S. listing because they are either unable to maintain investor recognition or to fulfill bonding expectations.

If a firm cross-lists, attracting initial international visibility, but it is unable to maintain this visibility, most of the long-run benefits of cross-listing will fail to materialize. Similarly, crosslisted firms that do not communicate with U.S. investors may not be able to effectively "bond" themselves to the U.S. market institutions because of residual information asymmetry issues. Richer information environments would allow U.S. market participants to better monitor managerial behavior, increasing the bonding effects. I posit that the management communication strategies of non-U.S. firms focused on U.S. audiences are related to cross-listed firms' success in maintaining higher levels of liquidity and valuation post cross-listing. Institutional ownership, media coverage, and analyst following are potential channels through which communication helps firms maintain the benefits of cross-listing. 
Although the association between investor communication and positive capital market outcomes when firms and investors are from the same country has been established in prior studies (e.g., Bushee and Miller 2012; Kirk and Vincent 2014), less is known about investor communication across country borders. Direct and indirect barriers to foreign investment that cannot be influenced by management, such as country-level corruption risk and pronounced differences between cultures, can prevent communication choices from having a significant relation to capital markets outcomes. Results from cross-sectional tests in this study support the idea that communication is more effective for firms from countries with lower perceived corruption and fewer cultural differences from U.S. culture.

A number of studies find that U.S. listings by non-U.S. companies are associated with positive valuation outcomes. However, only a few papers examine the importance of the information environment as a factor. These studies find that firms that most expand their shareholder base, analyst following, and media coverage exhibit the greatest increase in valuation around cross-listing (Foerster and Karolyi 1999; Baker, Nofsinger, and Weaver 2002; Lang, Lins, and Miller 2003a). Also, some firms are able to maintain these increases in valuation in the long run only if they also maintain a larger U.S. shareholder base over time (King and Segal 2009). These studies, at best, provide indirect evidence of a relation between firm-level information and the valuation benefits of cross-listing. They do not show specifically what managers do to achieve and maintain these benefits.

Managers often cite increased liquidity as one of the main perceived benefits of crosslisting. A commitment to increased disclosure after cross-listing can reduce adverse selection among buyers and sellers of the firm's shares increasing liquidity (Kyle 1985; Glosten and Milgrom 1985). While the valuation benefits of cross-listing have received relatively more 
attention in the literature, studies have also examined patterns in the stock liquidity of firms after they cross-list on U.S. markets (e.g., Smith and Sofianos 1997; Foerster and Karolyi 1998; Domowitz, Glen, and Madhavan 1998). They find that, on average, firms experience increases in stock liquidity after cross-listing. However, these studies also document significant cross-sectional variation in these stock liquidity patterns, depending on the level of domestic market development and firm size (e.g., Pulatkonak and Sofianos 1999; Halling, Pagano, and Zechner 2008; Silva and Chávez 2008). My analysis in this paper documents that investor communication strategies help explain the cross-sectional variation in stock liquidity of non-U.S. firms after cross-listing.

I focus on cross-listings in the U.S. for two reasons. First, U.S. institutional investors control roughly $50 \%$ of the total global assets under management. Listings in the U.S. thus provide non-U.S. firms with access to a large pool of potential investors. Second, U.S. investors have high expectations regarding the disclosure behavior of firms, which may increase the relevance of communication choices in this setting. My analysis covers four channels of investor communication: corporate access events held in the U.S., conference calls in English, press releases disseminated through newswires in English, and management forecasts. I assess these different forms of communication separately and together, using an investor communication score, both around the cross-listing period and in the long run after cross-listing.

I find that investor communication mitigates the post cross-listing decline in valuation documented by prior studies. ${ }^{2,3}$ My results indicate that the decline in valuation is steeper for firms that communicate with local investors prior to cross-listing, but do not communicate in the U.S.

\footnotetext{
${ }^{2}$ This result is robust to the exclusion of firms issuing shares in the U.S. at the time of cross-listing from the sample.

${ }^{3}$ I use Tobin's q and contemporaneous stock returns as measures of valuation in these tests. Results are qualitatively similar using both measures.
} 
post cross-listing, consistent with these firms not fulfilling communication expectations in the U.S. The investor recognition and bonding hypotheses predict a decline in cost of capital post crosslisting. Hail and Leuz (2009) investigate the association between cross-listing and implied cost of capital and find evidence that firms with cross-listings on U.S. exchanges experience a significant decrease in their cost of capital. I find that the decline in the cost of capital post cross-listing happens mainly for cross-listed firms that communicate with U.S. investors.

I also find that communication choices explain variation in the valuation and stock liquidity of cross-listed firms from the same country in the long run. These results are stronger for firms from countries with lower perceived corruption and fewer cultural differences from U.S. culture. In addition, I find that the valuation and liquidity of cross-listed firms are positively related to firms' U.S. institutional investor, media, and analyst following and that there is a positive and significant relation between communication and following variables post cross-listing. Therefore, I posit that increasing and maintaining institutional, media, and analyst following are potential mechanisms by which communication choices affect the valuation and stock liquidity of crosslisted firms.

Numerous studies document that cross-listed firms are valued at a premium relative to noncross-listed firms (e.g., Doidge, Karolyi, and Stulz 2004, 2009; Lang et al. 2003a). I compare the valuation of cross-listed and matched non-cross-listed firms, and I find that a significant portion of this valuation premium is associated with the investor communication practices of these groups of firms. Firms that cross-list but do not communicate with U.S. investors are not valued more highly than firms that do not cross-list. These results suggest that the cross-listing valuation premium is conditional on firms communicating with U.S. investors. 
Cross-listed firms in my sample have self-selected to communicate with investors. This may raise concerns that self-section bias impacts the empirical results. In an attempt to alleviate these concerns, I conduct a series of additional tests. First, I model the firm's decision to communicate with investors through corporate access. I use two-stage least squares regressions and the availability of direct flights between corporate headquarters and the U.S as a source of exogenous variation in firms' investor communication. ${ }^{4}$ I also control for firms' communication choices in the home market in these regressions. The results of the two-stage instrumental variable regressions are consistent with my predictions and main tests. Cross-listed firms that communicate more with U.S. investors and analysts have higher valuation and liquidity.

Increased valuation can be a result of increased growth expectations, decreased cost of capital, or both. Therefore, a related concern about the documented association between investor communication and the valuation of cross-listed firms is that it may reflect only the concurrent changes in firms' growth opportunities that do not stem from communication. In an attempt to account for this concern, I start by verifying that investor communication is significantly associated with reduced implied cost of equity capital for cross-listed firms. I then proceed by investigating whether my valuation results are sensitive to the type of news being disclosed. I divide observations into good and bad news firm-years, based on whether the average sentiment of firm-initiated press releases is positive or negative. My results suggest that levels of investor communication are positively associated with Tobin's q for both good and bad news firm-years.

\footnotetext{
${ }^{4}$ Since the availability of direct flights between two countries may be related to the levels of bilateral trade and foreign direct investment, in first- and second-stage regressions I control for country-year levels of foreign direct investment and exports and imports to the U.S. My results are robust to the inclusion of these variables.
} 
These findings help alleviate the concern that investor communication is positively related only to the valuation of cross-listed firms with positive growth expectations.

Financial reporting quality may play a role in communication effectiveness. Higher quality financial reporting may increase the credibility of voluntary disclosures (Gigler and Hemmer 1998). Exchange-listed firms in my sample are subject to additional financial reporting requirements and potentially higher SEC scrutiny than firms cross-listed over the counter. Evidence from Lang, Raedy, and Yetman (2003b) suggests that exchange cross-listed firms have higher quality earnings than OTC cross-listed firms. Consistent with the idea that financial reporting quality increases the effectiveness of voluntary investor communication, results from my cross-sectional tests suggest that, within country, exchange cross-listed firms benefit more from investor communication than OTC cross-listed firms. These results may be due to differences in the financial reporting quality and SEC scrutiny of firms in the various levels of listing.

Cross-listed firms have their shares trading in different markets and can, at least partially, choose which market participants (domestic or foreign) to communicate with. I take advantage of the fact that corporate access events tend to be catered to investors from the host country, and that cross-listed firms' shares trade in different countries, and in falsification tests, I investigate whether communication choices focused on non-U.S. investors relate to the liquidity in the U.S. and viceversa. I find that communication choices focused on domestic investors are not significantly associated with liquidity in the U.S., and that communication choices focused on U.S. investors are not significantly associated with liquidity in the firms' domestic markets. I also find that the proportion of domestic to U.S. communication events is negatively associated with the valuation of cross-listed firms, consistent with U.S. investors discounting these stocks because of increased perceived information disadvantages relative to domestic investors. 
The analysis that follows contributes to two existing bodies of literature: research on crosslistings and research on investor communication. Evidence from the literature on investor relations suggests that financial communication choices of U.S. firms are related to firms' domestic investor and analyst following (e.g., Bushee and Miller 2012; Kirk and Vincent 2014). Less is known about the effectiveness of investor communication when firms and investors are from different countries. The literature on cross-listing indicates that increased foreign investor recognition and richer information environments are related to the cross-listing valuation premium through increased investor and analyst following (Lang et al. 2003a; King and Segal 2009). To my knowledge, this study makes the first attempt to link these two strains of literature by examining variation in investor communication as a potential source of variation in cross-listing outcomes. Overall, my empirical findings suggest that investor communication is an important condition for firms to achieve the long-run benefits of cross-listing and should be accounted for when analyzing the valuation premium of cross-listed firms relative to non-cross-listed firms.

The literature review and research hypotheses follow in the next section. I discuss the sample and the variables in Section 3. Section 4 presents the research design and empirical evidence on the relation between investor communication and cross-listing outcomes. Section 5 concludes. 


\section{CHAPTER II}

\section{Related Literature and Hypothesis Development}

The effects of cross-listing shares abroad have been analyzed extensively (Karolyi 1998, 2006). Empirical evidence suggests two main explanations for the capital market outcomes of cross-listing: increased investor recognition associated with a broader shareholder base (the investor recognition hypothesis) based on Merton (1987), and better investor legal protection (the bonding hypothesis) proposed by Coffee $(1999,2002)$ and Stulz (1999). In this paper, I focus on communication choices as a mechanism through which cross-listed firms improve their information environments, increase investor recognition and reputational bonding, and achieve higher liquidity and valuations as a result.

Many of the empirical studies on cross-listings investigate the market valuation changes around a firm's international listing. Miller (1999) finds a positive 1.15\% average abnormal return for ADR announcement dates between 1985 and 1995. Foerster and Karolyi (1999) employ weekly abnormal returns for the two years around the U.S. cross-listing dates between 1976 and 1992 and not only find a significant listing week return of $1 \%$ on average but also uncover an interesting pre-listing run-up of abnormal returns of $19 \%$ and an average post-listing decline of $14 \%$. Consistent with Foerster and Karolyi's results, Mittoo (2003) finds that Canadian firms outperform the market by $30-40 \%$ in the year prior to cross-listing, but underperform Canadian market indexes by $13-30 \%$ over the three years after the U.S. listing. Using global listings, Sarkinsian and Schill (2009) expand the stock return analysis to longer windows between 1995 and 2005 and find that 
much of the valuation gains to overseas listings are not permanent and practically disappear five years after cross-listing. Gozzi et al. (2008) uncover a similar pattern analyzing the Tobin's q valuation ratio of cross-listings in the U.K and the U.S. between 1989 and 2000. They find that Tobin's q does not rise after cross-listing. Instead, q rises significantly before and during the crosslisting year but then falls sharply in the following year, quickly reversing the increases of the previous years.

Findings on the transitory nature of cross-listing benefits can be explained by the investor recognition hypothesis, as long as we assume that investor recognition peaks around cross-listing but then dissipates over time. According to Merton (1987), an increase in the number of investors who are aware of the firm's existence reduces its cost of capital. When few investors consider a particular stock in their investment universe, markets can clear only if some investors take very large and undiversified positions. These investors require higher returns to compensate for the higher risks they are taking, increasing the firm's cost of capital. Merton states that managers of such firms "should expend resources of the firm to induce investors who are not currently shareholders to incur the necessary costs of becoming aware of the firm" (p. 500). Consistent with Merton's theoretical analysis, Lehavy and Sloan (2008) find that investor recognition of a firm's stock can explain more of the variation in returns than fundamentals, such as earnings and cash flows.

Evidence from the cross-listing literature is consistent with Merton's investor recognition hypothesis: cross-listing increases awareness and contributes positively to valuation. Foerster and Karolyi (1999) find that the number of shareholders of cross-listed firms increases by approximately $30 \%$ around cross-listing. They also find that firms that expand their shareholder base the most exhibit the greatest increase in stock price around the listing announcement. Using 
a sample of Canadian firms, King and Segal (2009) show that not all firms exhibit higher valuations following a U.S. listing. The firms that benefit most are the ones that are successful in broadening their U.S. investor base. In addition, cross-listed firms experience increases in analyst following and media coverage, both of which are associated with an increase in valuation around the listing (Baker et al. 2002; Lang et al. 2003a).

Findings on the transitory nature of the cross-listing benefits are usually interpreted as inconsistent with the bonding hypothesis since better investor protection should produce enduring increases in valuation for cross-listed firms. If U.S. laws by themselves can actually deter foreign insiders from engaging in misappropriation and fraud (Coffee 1999) we should observe permanent increases in valuation. However, if we assume that SEC and other market participants' oversight of cross-listed firms are imperfect but can be facilitated by firms' information environments, and firms' information environments change over time, we could observe time-varying bonding effects.

Consistent with the idea that the litigation risk of cross-listed firms in the U.S. depends on the quality of firms' information environment, Beiting, Srinivasan, and Yu (2014) find that U.S. cross-listed foreign companies experience securities class action lawsuits at about half the rate as do U.S. firms. However, once a lawsuit triggering event occurs, they find no difference in the litigation rates between a foreign and comparable U.S. firm. This evidence suggests that the litigation risk of cross-listed firms is constrained by transaction costs, but the effect of transaction cost can be significantly reduced in the presence of quality information triggers that reveal potential misconduct of the firm.

Siegel (2005) provides further evidence for the notion that increased investor and analyst oversight could benefit cross-listed firms. In his detailed analysis of evidence from Mexican firms, 
he notes that some insiders exploited SEC's weak legal enforcement of cross-listed firms. By contrast, managers from other cross-listed firms emerged from an economic downturn with a clean reputation and went on to receive privileged long-term access to outside finance. Siegel proposes that reputational bonding of cross-listed firms can be strengthened even more when the U.S. information environment is stronger. Increasing media and analyst scrutiny strengthen reputational bonding, and firms gain better access to capital. Even without effective legal enforcement, the investor communication and subsequent following can enable cross-listed firms to bond themselves by building their reputation.

Overall, the cross-listing literature provides evidence consistent with changes in valuation around cross-listing being associated with changes in investor, media, and analyst following during the same period. The disclosure literature, on the other hand, provides evidence on the association between corporate communication and institutional ownership, media coverage, and analyst following. Lang and Lundholm (1993) find that U.S. companies with higher analysts' evaluations of firms' disclosures have larger analyst following, less dispersion in analyst forecasts, and less volatility in forecast revisions. Francis, Hanna, and Philbrick (1997) find that there is an increase in analyst coverage for firms making presentations to the New York Society of Securities Analysts. Analyzing firms that have significant and sustained improvements in their analysts' ratings of firms' disclosures, Healy, Hutton, and Palepu (1999) show that disclosure rating increases are accompanied by analyst following increases. In addition, the prior literature on investor relations indicates that the investor communication choices of U.S. firms are related to U.S. institutional investor, media coverage, and analyst following (Bushee and Miller 2012; Bushee, Jung, and Miller 2011; Kirk and Vincent 2014; Kirk and Markov 2016). Using a survey of global firms in 
2012, Karolyi and Liao (2015) find that responses on IR activities are associated with higher analyst following and increased Tobin's q.

Taken together, theory and evidence from the cross-listing and financial communication literature suggest that investor communication could prevent the decline in valuation after crosslisting by helping firms to maintain better information environments and higher levels of investor recognition and reputational bonding. My first hypothesis is, therefore, the following:

\section{H1: The decline in valuation post cross-listing is mitigated by investor communication.}

Besides looking at the valuation changes around a firm's international listing, many studies investigate cross-sectional differences in the valuation of cross-listed firms in the long run. These studies usually use Tobin's q as a measure of valuation and compare the valuation ratios of crosslisted and non-cross-listed firms. They find that in the long run after cross-listing, cross-listed firms tend to be valued more highly than their non-cross-listed counterparts. The literature usually refers to this difference in valuation as the cross-listing valuation premium.

Doidge et al. (2004) use the Worldscope database universe of firms and find that firms listed in the U.S. have Tobin's q ratios that are $16.5 \%$ higher than the q ratios of firms from the same country that do not list in the U.S. However, the valuation premium seems to be conditional on firms keeping high levels of institutional ownership. King and Segal (2009) find that crosslisted Canadian firms with a single class of shares that attract few or no U.S. investors are valued no differently than non-cross-listed Canadian firms, after controlling for firm characteristics.

While studies have sought to explain the cross-sectional variation in the long-run benefits of cross-listing, little attention has been paid to the role of voluntary disclosure. Economic theory predicts a negative association between voluntary disclosure and cost of equity capital (e.g., Diamond and Verrecchia 1991; Easley and O'Hara 2004). In accordance with this idea, Baginski 
and Rakow (2012) examine the relation between management earnings forecast disclosure and the cost of equity of U.S. firms after Reg FD. They find evidence of a negative association between the quality of management earnings forecasting policy and the cost of equity.

Using a sample of U.S. firms presenting at broker-hosted investor conferences, Green, Jame, Markov, and Subasi (2014) find that conference firms experience a 0.03 increase in Tobin's $\mathrm{q}$ in the year following the event. Using a sample of U.S. and non-U.S. firms, Karolyi and Liao (2015) analyze the results of a 2012 global survey of Investor Relations officers and find that more active IR programs are associated with a $12 \%$ higher Tobin's q valuation ratio. Activity is measured by responses to the firms' involvement in broker-sponsored conferences, one-on-one meetings with institutional investors, global outreach, formal disclosure, media and governance policies. According to Karolyi and Liao (2015), the cost of capital is the channel that links IR and market value.

Given the theoretical and empirical evidence cited above, my second hypothesis is as follows:

H2: Investor communication choices are associated with higher levels of valuation in the long run after cross-listing.

A U.S. listing may also result in increased stock liquidity, as cross-listing can be perceived as a commitment to increased disclosure and, therefore, reduce adverse selection among buyers and sellers of the firm's shares. Surveys of managers indicate that increased liquidity is one of the main perceived benefits of cross-listing. However, empirical evidence suggests significant variation in the liquidity benefits of cross-listing. Using a sample of Canadian firms that cross-list in the U.S., Foerster and Karolyi (1998) find that overall bid-ask spreads in the domestic market decrease after cross-listing. However, the decrease in trading costs is concentrated in those stocks 
that experience a significant shift of total trading volume to the U.S. exchange after listing. Using a sample of firms from Latin American countries, Silva and Chávez (2008) find that larger crosslisted firms from specific countries seem to benefit from improved liquidity, but the liquidity benefit cannot be generalized to smaller cross-listed firms. This variation in the liquidity outcomes of cross-listing can be a result of variation in the information asymmetry between local and U.S. investors for different firms.

Diamond and Verrecchia (1991) and Kim and Verrecchia (1994) propose that voluntary disclosure reduces information asymmetries among informed and uninformed investors. As a result, firms with high disclosure experience an increase in stock liquidity. These studies also argue that greater disclosure and stock liquidity will be associated with increased institutional ownership. Given the theoretical and empirical evidence cited above, my third hypothesis is as follows:

H3: Investor communication choices are associated with higher levels of stock liquidity in the U.S. market in the long run after cross-listing. 


\section{CHAPTER III}

\section{Sample and Variables}

\section{Sample and Descriptive Statistics}

My period of analysis is from 2004 to 2014. I restrict my analysis to this period because the coverage of investor communication activities of non-U.S. firms prior to 2004 is relatively limited on Bloomberg, I/B/E/S Guidance and Factiva. My sample comprises non-U.S. firms that cross-listed their shares in the U.S. between 2006 and 2013, including both exchange and overthe-counter listings, and a matched sample of firms cross-listed in the U.S. prior to 2006 from the same country and industry, and closest in size to my sample of 2006-2013 cross-listings. The rationale for matching cross-listings between 2006 and 2013 to older cross-listings is to keep comparable samples for tests around cross-listing and in the long run after cross-listing. In order to measure the relation between communication choices and the valuation of cross-listed firms relative to non-cross-listed firms, I also match my main sample of cross-listed firm-years to a control sample of non-cross-listed (domestic) firm-years from the same country and industry and closest in size, as measured by total assets in U.S. dollars. 
The list of cross-listed firms was obtained from EDGAR 20-F and 6-K filings, ${ }^{5}$ as well as the Bank of New York, Citibank and JP Morgan lists of ADRs. Cross-listing dates are collected from the depositary banks' lists, as well as from CRSP.

Table 1 describes the sample selection process. I exclude firms that do not have the necessary data to construct my variables in Datastream, as well as firms with negative shareholders' equity and total assets less than 10 million USD. Table 2 panel A provides the summary statistics separately for the 2006-2013 cross-listings, cross-listings made prior to 2006, and non-cross-listed firms. Cross-listed firms not only tend to be larger than non-cross-listed firms but also have higher sales growth and Tobin's q. Cross-listed firms also have higher investor and analyst following. Importantly for my analysis, they communicate more frequently with investors. Panel B outlines the distribution of observations by country. No country in the sample comprises more than $15 \%$ of the observations. Countries with the highest number of observations are Australia (14.6\%), China (12.3\%), the U.K. (9\%), Canada (8\%), and Brazil (7.2\%). Panel C presents the correlation matrix. Important for my analysis are the positive and significant correlations between the four communication variables, between corporate access in the home country and in the US, and between the communication variables and institutional ownership, analyst following, liquidity measures, and Tobin's q.

The positive correlation between the four communication choices suggests that firms tend to use these channels simultaneously. I explore the relation among communication variables in more detail in Table 3. Table 3 panel A presents the characteristics of cross-listed firm-years by each investor communication choice. Of the cross-listed firms that decide to attend at least one

\footnotetext{
${ }^{5}$ I thank David Maber and Jason V. Chen for providing this data.
} 
corporate access event in the U.S., $86 \%$ also hold at least one English conference call, $80 \%$ distribute at least one press release in English through the newswires, and 44\% also disclose at least one management forecast during the year. Of the firms that decide to distribute at least one English press release during the year, $31 \%$ also attend at least one corporate access event in the U.S., 70\% hold an English conference call, and 33\% disclose a management forecast. Overall, the descriptive statistics in panel A suggest that firms that attend corporate access events and disclose management forecasts also tend to use other channels, while firms that hold conference calls and distribute press releases do not necessarily use other channels.

Table 3 panel B presents the results of the factor analysis of the four communication variables using principal-component factors. The least common communication choices are management forecasts and corporate access events in the U.S. The most common communication choices are conference calls and press releases. The findings in panels A and B support the idea that corporate access and management forecasts are more costly and less frequently used, while press releases and conference calls are less costly and more widespread channels of investor communication.

\section{Variables}

My main explanatory variables of interest reflect management communication choices focused on U.S. investors. These variables include the number of corporate access events held in the U.S., conference calls in English, firm-initiated press releases in English disseminated through newswires, and management forecasts. Data on corporate access events is collected from the Bloomberg Corporate Events database and includes capital market conferences, investor days, and non-deal roadshows held in the U.S. Given time and monetary costs of managers' international 
travel, I assume that managers who travel to participate in investor conferences will also hold oneon-one meetings during their time in the U.S. Therefore, I include attendance in investor conferences in my measure of U.S. investors' access to management events.

Since I want to capture only events catering to U.S. investors, I hand-collect the location of corporate events with that information missing in Bloomberg, and I exclude those events for which I could not identify the venue based on a web search. I assume that firms without event data on Bloomberg did not hold events in the U.S. during that year. Data on conference calls is also collected from Bloomberg. Data on firm-initiated press releases is gathered from Factiva and includes press releases disseminated through PR Newswire and Business Wire. I collect management forecasts from I/B/E/S Guidance and include any type and horizon of management guidance disclosed by the firm during the year. Given that my communication variables are significantly correlated and may represent one common latent factor, I construct an investor communication score using factor analysis. The scoring coefficients on each of the communication variables are presented in Table 3 panel B.

The investor communication activities analyzed in this study are voluntary, therefore, it is important to understand what firm and country characteristics are associated with these choices. Table 3 panel $\mathrm{C}$ presents the results for the determinants of the decision of cross-listed firms to communicate with U.S. investors. Firms that hold more corporate access events in their home country tend to communicate more in the U.S. as well, suggesting a positive relation between firms' domestic and international communication choices. Larger firms, that cross-list in an exchange (versus over-the-counter), that have a higher proportion of international sales, and that are issuing equity also communicate more. 
I find that lead asset growth is not significantly associated with investor communication. Similar results are obtained using lead and lagged sales and capex growth. Lead earnings growth is only weakly positively associated with investor communication choices. These results partially mitigate the concern that firm growth is an omitted correlated variable in the outcome regressions analyzed later in this paper. To measure future realized growth, I calculate the percentage change in sales, assets, capital expenditures and earnings from year $t$ to year $t+1$. Asset growth and capital expenditures are used in prior studies as measures of corporate investment (e.g., Beatty, Liao, and Yu 2013; Shroff, Verdi, and Yu 2014). I focus on lead changes under the assumption that the firm changes its current period communication based on expectations about future performance, and that current expectations are positively correlated to future realizations of firm growth.

Within and across countries, IFRS mandates are positively associated with investor communication of cross-listed firms. Across countries, firms from countries that are more culturally similar to the U.S, that have English as an official language, that have a civil legal tradition, and that have higher levels of corruption communicate more. These results are consistent with lower cultural and language barriers ${ }^{6}$ reducing the costs of communication. Firms from countries with civil legal tradition and higher corruption levels may communicate more in an attempt to overcome the weaker institutions in their home markets.

Appendix 1 offers definitions of all variables used in the empirical tests. Following prior studies in the cross-listing literature, I use Tobin's q as my main dependent variable representing

\footnotetext{
${ }^{6}$ Even though firms from countries where English is an official language tend to communicate more with U.S. investors, there is still significant variation in the communication choices of firms from English speaking countries. For example, around 59\% of the English speaking cross-listed firms in my sample do not hold conference calls, and $50 \%$ do not disseminate press releases through newswires.
} 
the benefits of cross-listing. ${ }^{7}$ Tobin's q is computed as the ratio of total assets less the book value of equity plus the market value of equity in the numerator and book value of assets in the denominator as of the end of the fiscal year. I replicate my main valuation results using a cost of capital measure that follows the methodology in Claus and Thomas (2001). As increased liquidity is also mentioned as one of the main benefits of cross-listing, I also include two measures of stock liquidity as dependent variables: average bid-ask spreads and shares turnover. Since my explanatory variables aim to capture communication efforts aimed at U.S. investors, both liquidity measures are computed in the U.S. market. I use the following control variables in all regressions: firm size, equity issuance, internationalization of sales, IFRS mandates, future growth opportunities, leverage, and profitability. Firm size is computed as the log of total assets in U.S. dollars. Equity issuance is an indicator variable equal to one when the firm issues shares during the year. I proxy internationalization using the ratio of international sales to total sales during the year. I proxy future growth opportunities using sales growth computed as the percent change in sales from year t-1 to year t. Leverage is calculated as total debt divided by total assets. Profitability is measured by the return on assets (ROA), calculated as net income scaled by total assets.

To compute my institutional ownership variables, I sum U.S. institutional positions using the holdings by 6-digit Cusip from Thomson-Reuters Institutional Holdings and Thomson-Reuters Mutual Funds Databases. I delete duplicates by manager code before adding the holdings of the two databases. Number of Institutions is the number of distinct institutional investors. As Bradshaw, Bushee, and Miller (2004) point out, in the presence of restrictions on foreign ownership magnitudes, different levels of free float across countries, or large block investments,

\footnotetext{
${ }^{7}$ King and Segal (2009), Doidge, Karolyi, and Stulz (2004, 2009), Gozzi, Levine, and Schmukler (2008), and Lang, Lins, and Miller (2003) use Tobin's q to assess the impact of cross-listing.
} 
this measure can provide a better measure of U.S. institutional interest in a stock than the percentage of institutional holdings. I assume that firms with no U.S. institutional investor holdings data have zero U.S. institutional ownership. Number of Analysts is the number of distinct analysts issuing forecasts of the company's earnings during the calendar year according to $\mathrm{I} / \mathrm{B} / \mathrm{E} / \mathrm{S}$.

It is important to note that country-level characteristics may also affect U.S. holdings of foreign stocks. These characteristics include close geographical proximity, a high number of U.S. listings, credible accounting information, high disclosure requirements, and low transaction costs on the home exchange. I assume that these characteristics do not vary during my period of analysis and are appropriately accounted for using country fixed effects. Later on, I relax this assumption by using a matched country and industry control sample. In untabulated tests, I also run regressions using country-year fixed effects. All continuous variables are winsorized at the $1 \%$ and $99 \%$ levels. 


\section{CHAPTER IV}

\section{Research Design and Findings}

Communication choices may be important in mitigating decreases in valuation post crosslisting, as well as in maintaining higher valuations and liquidity in the long run. My main tests, therefore, include regressions of valuation and cost of capital on investor communication choices around the cross-listing period for firms cross-listed between 2006 and 2013, and after cross-listing for both 2006-2013 cross-listings and a sample of older cross-listings (firms cross-listed prior to 2006). Since my liquidity variables are measured in the U.S. market, all liquidity tests are performed after cross-listing.

\section{Relation between Communication and the Decline in Valuation Post Cross-Listing}

I start my tests by examining the relation between the decline in valuation and investor communication post cross-listing. If we assume that investor recognition can be transitory, communication strategies aimed at maintaining investor recognition can be critical in cementing the permanent valuation gains from a U.S. listing (King and Mittoo 2007). Firms may experience increases in visibility around the time of cross-listing, but attention to these firms may fade away if firms do not take actions to maintain it in the long term. Thus, investor communication may be important in keeping and attracting visibility after cross-listing takes place. In addition, investor communication can be an important component of the bonding process of cross-listed firms in the 
U.S. market. In an attempt to capture the relation of investor communication and the decline in valuation in the years post cross-listing, I estimate the following regression:

$$
\begin{aligned}
& \text { Valuation Variable }_{i t}=\beta_{0}+\beta_{1} \text { Post }_{i t}+\beta_{2} \text { High Communication }_{i t} \times \text { Post }_{i t}+\beta_{3} \text { High Communication }_{i t} \\
&+\beta_{4} \text { Equity Issuance }_{i t}+\beta_{5} \text { International Sales }_{i t}+\beta_{6} \text { IFRS }_{i t}+\beta_{7} \text { Log Assets }_{i t} \\
&+\beta_{8} \text { Sales Growth }_{i t}+\beta_{9} \text { ROA }_{i t}+\beta_{10} \text { Leverage }_{i t}+\text { Industry FEs }_{i} \\
&+ \text { Country FEs }_{i}+\text { Year FEs } \\
&+
\end{aligned}
$$

I cluster standard errors in all regressions by firm. My main valuation variable is Tobin's q. I also estimate regression (1) using cost of capital and contemporaneous annual stock returns as alternative dependent valuation variables. High Communication is an indicator variable that equals one for the upper quartile of the investor communication score for cross-listed firms. To investigate the relation between investor communication and firm valuation, I control for firm characteristics that have been shown to determine firm valuation in the cross-listing setting (e.g., Lang et al. 2003a; King and Segal 2009), such as sales growth, book leverage, book value of total assets and return on assets. Sales growth is a proxy for a firm's growth opportunities. Log of book value of total assets is used to proxy for firm size. ROA is used to control for firm profitability. Since equity issuance may be associated with current valuation and incentives to communicate, I also control for firms' equity issuance during the year. Within country, changes in accounting standards can be associated with changes in valuation, thus I control for IFRS mandates in all regressions. More internationalized firms can have higher valuations and also more incentives to communicate, therefore I control for firms' proportion of international sales. Finally, valuation may differ across firms because of potentially unobservable country/industry sources of heterogeneity. For this reason, I include country and industry fixed effects.

Figure 1 presents the average Tobin's q around cross-listing (years $[-2,-1]$ versus $[+1,+2]$ ) for sample firms with high and low investor communication. Firms with investor communication 
scores in the upper (lower) quartile are considered high (low) investor communication firms. The univariate evidence in this plot suggests that firms with low investor communication experience a sharp decline in valuation post cross-listing, but high investor communication firms do not.

Table 4 panel A presents multivariate regressions quantifying the valuation ratio pre- and post-cross-listing, the year of cross-listing being the first year that Post equals one. Column 1 shows the regression results of Tobin's q on the control variables and an indicator variable for post cross-listing years. Thus, the valuation ratio in years prior to cross-listing is captured by the intercept. The results in column 1 indicate that, after I control for firm and country characteristics, on average cross-listed firms experience a decrease in Tobin's q of -0.08 in the years following cross-listing in relation to the years preceding cross-listing. For the average cross-listed firm in my sample, this represents a decrease of 5\% in Tobin's q. This finding is consistent with prior studies. King and Segal (2009) document a decrease of 15\% in Tobin's q in the years post cross-listing for a sample of Canadian firms cross-listed in the U.S. between 1988 and 2005.

In column 2, I examine how investor communication interacts with this decline in valuation. The coefficient on the interaction of Post and communication is positive and significant, indicating that the average decline in valuation post cross-listing is driven by low communication firms. ${ }^{8,9}$

Researchers have documented the poor performance of long-run stock returns following equity offerings, consistent with managers timing offerings when the stock price is overvalued

\footnotetext{
${ }^{8}$ Results in table 4 are robust to the exclusion of observations from years 2007, 2008, and 2009 from the regressions.

${ }^{9}$ In untabulated tests, I exclude all control variables and run the regressions including only the investor communication variable and country, year and industry fixed-effects. The results are qualitatively the same, mitigating concerns of a mechanical relation between Tobin's q and the control variables influencing the results.
} 
(Loughran and Ritter 1995). Equity offerings can provide incentives for managers to inflate prices through firm disclosures to extract rents from purchasing investors at issuance. Lang and Lundholm (2000) suggest firms can use voluntary disclosures to hype their stock before issuing equity. Using a sample of 41 offering U.S. firms and a matched sample of 41 non-offering U.S. firms, they find that offering firms increase their disclosure before the announcement and that the increase in disclosure is negatively associated with post-offer stock returns. Shroff, Sun, White and Zhang (2013) examine whether the pre-seasonal equity offerings (SEO) disclosures are associated with an unwarranted increase in the firm's stock price, as evidenced by the association between pre-SEO good news disclosures and post-SEO abnormal returns. They find no evidence that pre-SEO good news forecasts or press releases are associated with post-SEO return reversal.

In order to investigate whether my results are sensitive to firms' equity offering decisions, in column 3, I exclude firms that are offering shares in the U.S. at the time of cross-listing. ${ }^{10}$ The results are qualitatively the same. ${ }^{11}$ The decline in valuation post cross-listing is mitigated by investor communication for firms that offer and do not offer shares at the time of cross-listing.

In columns 7 to 9 , I replicate the Tobin's q results using contemporaneous annual stock returns as an alternative valuation measure. Results are consistent with the Tobin's q regressions and suggest that investor communication significantly mitigates the decline in stock returns post cross-listing.

Both the investor recognition and bonding hypothesis predict a decline in the cost of capital post cross-listing. In columns 4 to 6 , I investigate whether investor communication is associated

\footnotetext{
${ }^{10}$ Namely, Level III listings and 144A private placements.

${ }^{11}$ In untabulated tests, I also exclude all firm-years with stock issuances in the U.S. and in other markets greater than $1 \%$ of firms' shareholders' equity. The results are qualitatively the same.
} 
with this predicted decline. My results suggest that cross-listed firms with high U.S. investor communication scores experience a significant decline in cost of capital post cross-listing, but the same cannot be said about low communication firms.

Given the positive association between investor communication in the home country and in the U.S. post cross-listing documented in table 3 panel C, U.S. investors may try to predict future U.S. communication practices of cross-listed firms by looking at their levels of communication with local investors prior to cross-listing. In table 4 panel B, I split the sample of 2006-2013 cross-listings into high and low communication at home pre cross-listing subsamples. I use the number of corporate access events in the home country prior to cross-listing as a proxy for investor communication at home in that period. I find that firms that communicate at home but do not maintain the same levels of communication in the U.S. post cross-listing experience larger declines in valuation, measured by both Tobin's q and annual stock returns. This result is consistent with these firms failing to fulfill U.S. investors' expectations regarding their communication choices in the U.S.

\section{Valuation and Liquidity of Cross-listed Firms and Investor Communication Choices in the \\ Long Run}

My main and second set of tests examine the relation between communication choices and the valuation and liquidity of cross-listed firms in the long run after cross-listing using the following specification:

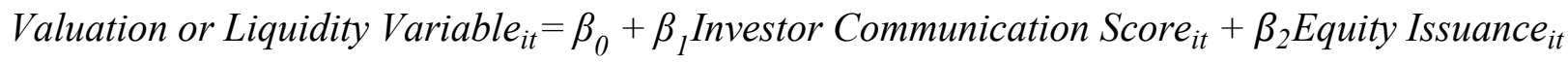

$$
\begin{aligned}
& +\beta_{3} \text { International Sales }_{i t}+\beta_{4} \text { IFRS }_{i t}+\beta_{5} \text { Log Assets }_{i t} \\
& +\beta_{6} \text { Sales Growth }_{i t}+\beta_{7} \text { ROA }_{i t}+\beta_{8} \text { Leverage }_{i t} \\
& + \text { Industry FEs }_{i}+\text { Country FEs }_{i}+\text { Year FEs }_{t}+\varepsilon_{i t}
\end{aligned}
$$


I include industry, country, and year fixed effects. I choose not to include firm fixed effects for two reasons. First, since one of my main goals in this paper is to explain the cross-sectional variation in cross-listing benefits documented by prior literature, I choose to follow the specification in the majority of studies in the area. Second, given that my period of analysis is not extensive, many firms in my sample have few observations. In addition, communication choices are fairly sticky and do not vary much within firm. ${ }^{12}$ With few observations per unit and variables that vary little within each unit, relative to the amount of variation in the outcome variable, estimates of the within-unit effects may then diverge considerably from the true effect due to chance alone. Another related drawback of a firm fixed-effects model in my sample is that it requires the estimation of a parameter for each firm, i.e., 758 new parameters for a sample of 3,347 observations. This can substantially reduce the model's power and increase the standard errors of the coefficient estimates.

Table 5 panel A column 1 presents the results from the estimation of (2) using Tobin's q as a dependent variable. The investor communication factor is significantly and positively associated with the Tobin's q ratio in the years after cross-listing. ${ }^{13,}$ 14, 15 The results are also economically significant. For the average cross-listed firm in my sample, one standard deviation

\footnotetext{
${ }^{12}$ Some communication choices are less sticky than others. The number of corporate access events tend to vary more within firm than, for example, the number of conference calls. In untabulated tests, I include firm fixed-effects to regressions of corporate access on valuation, cost of capital and liquidity and the results indicate that within-firm changes in the number of access events are associated with capital market benefits for cross-listed firms.

${ }^{13}$ My primary results are robust to the one-by-one exclusion of each of the main countries in my sample: namely, Australia, Brazil, Canada, China and the United Kingdom.

${ }^{14}$ In untabulated tests, I include country-year fixed effects to control for time varying changes in country characteristics. The results are qualitatively the same.

${ }^{15}$ Since the communication variables are measured throughout the year, and the Tobin's q is computed on the last day of the year, one can interpret results for the Tobin's q regressions as lead valuation on lagged communication.
} 
increase in the investor communication score is associated with a 7.2\% increase in Tobin's q. This coefficient is smaller but consistent with those of Karolyi and Liao (2015). Using the results of a 2012 survey of Investor Relations officers, Karolyi and Liao (2015) find that more active IR programs are associated with a $12 \%$ higher Tobin's q valuation ratio.

The coefficient on investor communication also appears to be relevant when compared to the coefficients on the control variables usually included in cross-listing valuation studies. A one standard deviation increase in the investor communication score is associated with an average 0.12 increase in Tobin's q. On the other hand, a one standard deviation increase in the log of assets, a commonly used measure in the cross-listing literature, is associated with an average 0.10 decrease in Tobin's q, and a one standard deviation increase in ROA is associated with an average 0.13 decrease in Tobin's q. These findings suggest that it is important to account for investor communication choices when analyzing the valuation effects of cross-listing.

The economic magnitude of investor communication is also comparable to the magnitudes of coefficients in papers investigating the valuation effects of corporate governance in international settings. For example, Durnev and Kim (2005) find that a one standard deviation increase in their comprehensive governance score results in a 9\% increase in Tobin's q. Aggarwal et al. (2009) find that decreasing an average firm's governance score by the average governance gap between an international firm and a matching U.S. firm would reduce Tobin's q by $6.2 \%$.

Although investor communication activity is associated with an effect on firm value comparable to that of governance choices, one can find the size of the relationship surprisingly large. However, we must consider that the costs of such communication activities could be large and include costs of regulatory compliance, litigation risk, proprietary costs of disclosure and the indirect cost of executives' time. Additionally, the effect of investor communication on firm value 
is likely non-linear in firm size. In unreported tests, I run regression (2) by quartiles of total assets in USD and find that the association between investor communication and Tobin's $\mathrm{q}$ is economically larger among small firms. For firms in the bottom two quartiles of size, a onestandard-deviation increase in investor communication is associated with a 0.18 higher Tobin's q or $11 \%$ of its unconditional mean (1.65). For firms in the top two quartiles by size, the equivalent result is a 0.04 higher Tobin's q ratio or less than $3 \%$ of its mean (1.41).

A potential concern about the documented association between investor communication and the valuation ratio of cross-listed firms is that it may reflect only the concurrent changes in firms' growth opportunities that do not stem from communication, although communication may still be important in communicating these changes in opportunities to U.S. investors. Increased valuation can be a result of increased growth expectations, decreased cost of capital, or both. Economic theory and prior evidence would predict that greater voluntary disclosure and increased firm visibility through investor communication lowers the cost of capital. I find results consistent with these predictions. Specifically, results in Table 5 panel A column 2 indicate that investor communication choices are negatively associated with implied cost of capital. ${ }^{16}$ Although the effects of expected cash flows and cost of capital on firm value are hard to disentangle, the evidence on Table 5 suggests that at least a portion of the positive association between investor communication and valuation is due to decreased cost of capital as predicted by theory. ${ }^{17}$

Increased stock liquidity is also a frequently mentioned benefit of cross-listing. I examine the relation between stock liquidity in the U.S. and investor communication of cross-listed firms.

\footnotetext{
${ }^{16}$ I follow Karolyi and Liao (2015) and measure the implied cost of capital using the residual income valuation model of Claus and Thomas (2001) and analyst forecasts.

${ }^{17}$ Untabulated tests confirm the negative relation between implied cost of capital and Tobin's q for firms in my sample.
} 
Table 5 panel B presents the results of the regressions of turnover and bid-ask spreads on investor communication and a set of controls. Investor communication score is significantly and positively associated with share turnover in the years after cross-listing and negatively associated with average bid-ask spreads. For the average cross-listed firm in my sample, a one standard deviation increase in the investor communication score is associated with an $18 \%$ decrease in bid-ask spreads in the U.S. To provide some context, an increase of one standard deviation in the mean investor communication score represents going from a median of 0 to 2 corporate access events in the U.S. per year, from 0 to 4 conference calls in English, from 27 to 29 press releases in English and from 0 to 1 management forecast.

\section{Institutional, Media, and Analyst Following: Path Analysis}

Given the evidence from prior literature on the association between investor recognition and the benefits of cross-listing, I analyze the relation between institutional, media, and analyst following and investor communication choices in the long run after cross-listing, using the following regression specification:

$$
\begin{aligned}
\text { Following Variable }_{i t}= & \beta_{0}+\beta_{1}{\text { Investor Communication } \text { Score }_{i t}+\beta_{2} \text { Equity Issuance }_{i t}} \\
& +\beta_{3} \text { International Sales }_{i t}+\beta_{4} \text { IFRS }_{i t}+\beta_{5} \text { Log Assets }_{i t} \\
& +\beta_{6} \text { Sales Growth }_{i t}+\beta_{7} \text { ROA }_{i t}+\beta_{8} \text { Leverage }_{i t} \\
& + \text { Industry FEs }_{i}+\text { Country FEs }_{i}+\text { Year FEs }_{t}+\varepsilon_{i t}
\end{aligned}
$$

Table 5 panel B column 1 presents the estimated $\beta_{1}$ coefficients on investor communication from (3). The results indicate that the investor communication score is positively and significantly associated with the number of institutional investors, the number of media articles and the number of analysts following the firm. The results are also economically significant. One 
standard deviation increase in the investor communication score is associated with an increase of 5.9 U.S. institutional investors, 1.9 analysts and 5.7 media articles.

After confirming that communication and analyst and institutional following are indeed positively associated, I verify whether institutional, media, and analyst following are positively associated with firm valuation and stock liquidity. Consistently with prior literature, I find that the number of U.S. institutional investors, media articles, and analysts following are positively related to Tobin's q and liquidity of cross-listed firms.

In addition to the analyst, media, and institutional following variables, I include the investor communication score as an explanatory variable in these regressions. This specification controls for institutional, media, and analyst following to examine whether communication has a direct effect on valuation and liquidity that is incremental to communication's effect through analysts, media, and institutions. Table 5 panel B column 3 presents the coefficients on the investor communication variable in these regressions. The coefficients are significant in the regressions for Tobin's q, cost of capital, and turnover, indicating a direct association between communication and these outcomes that does not depend on increases in following.

Table 5 panel B presents a summary of the indirect, direct and total path estimates. An important caveat to path estimates using regressions is that it can only estimate nonrecursive models, i.e., unidirectional models without feedback loops or any reciprocal effects. In other words, this specification treats analyst, media, and institutional following as if they have a unidirectional causal effect on stock price and liquidity; however, analysts, media outlets, and investors may be responding to prices and liquidity levels as well. Thus, I can only conclude from these models that the contemporaneous outcomes tend to be associated with each other not that one outcome causes another. 
With this caveat in mind, the results in panel B suggest that investor communication has a direct and indirect association with Tobin's q and share turnover, through institutional, media, and analyst following, a direct and indirect association with cost of capital, and an indirect association with bid-ask spreads. The indirect associations with cost of capital and bid-ask spreads happen through analyst following, but not through institutional ownership and media coverage. Overall, results are consistent with analyst following being the channel that links investor communication to reduced levels of information asymmetry and cost of capital for cross-listed firms.

\section{Investor Communication and Likelihood of Delisting}

Firms that cross-list, do not communicate with U.S. investors and, therefore, do not achieve the full benefits of cross-listing may be more likely to delist from the U.S. market. In table 5 panel C, I investigate whether firms with lower investor communication in the U.S. are more likely to delist in the future. The results are consistent with this prediction, cross-listed firms with lower investor communication score are more likely to eventually delist from the U.S.

\section{Cross-sectional Tests}

The relation between investor communication and valuation may vary by country and firm characteristics. Certain barriers to foreign investment, such as levels of corruption or cultural distance, cannot be lifted by management; such barriers can prevent communication choices from affecting cross-listing outcomes significantly. Conversely, it is possible that individual firms' communication strategies are not very effective in the presence of significant cultural differences and high perceived corruption levels. Furthermore, non-U.S. firms can list in the U.S. through different types of listings. These different types of listings have different disclosure and 
governance requirements, which can, in turn, affect the relation between investor communication and firm valuation.

\section{Cultural Distance}

In order to investigate how the relation between communication and the valuation of crosslisted firms varies by country characteristics, I start by partitioning the sample between firms from countries with high and low cultural distance. Cultural distance scores are measured as the average of the differences in the scores for Hofstede's six cultural dimensions between the U.S. and the firm's country. The six dimensions are the power distance index, individualism versus collectivism, the uncertainty avoidance index, masculinity versus femininity, long-term orientation versus short-term orientation, and indulgence versus restraint. Firms from countries with cultural distance scores greater than the sample median are considered high cultural distance firms. Columns 1 and 2 in Table 6 present the results. Investor communication is positively and significantly associated with the valuation of cross-listed firms in both subsamples. However, this association is more positive for firms from countries with less cultural distance from the U.S., consistent with the idea that cultural distance could decrease the effectiveness of communication.

\section{Language}

On the one hand, language barriers can increase U.S. investors' costs in processing firm disclosures made in the local language, thus increasing the benefits of investor communication in English for firms from countries where English is not the official language. On the other hand, language barriers can also decrease the effectiveness of communication if managers are not fluent in English. Using transcripts from non-U.S. firms' English conference calls, Brochet, Naranjo, and 
$\mathrm{Yu}$ (2016) find that the calls of firms in countries with greater language barriers are more likely to contain non-plain English and erroneous expressions, and that calls with a greater use of non-plain English and erroneous expressions show lower capital market responses.

Lundholm, Rogo, and Zhang (2014) examine the readability of text and the use of numbers in the annual filings and earnings press releases of foreign firms listed on U.S. stock exchanges. They find that cross-listed firms tend to write clearer text and present more numerical data than their U.S. firm counterparts, suggesting that cross-listed firms may use clearer written disclosures in an attempt to overcome U.S. investors' home bias.

In table 6 panel A columns 3 and 4, I partition the sample between firms from countries where English is the official language and countries where English is not the official language. The coefficient on investor communication is positive and significant in both subsamples, and although larger for the non-English subgroup, the difference is not statistically significant.

\section{Perceived Corruption}

Corruption risk may also represent a barrier to foreign investment and affect the association between communication and firm valuation. I measure this factor using the Worldwide Governance Indicators (WGI). The WGI control of corruption score captures perceptions of the extent to which public power is exercised for private gain, including both petty and grand forms of corruption, as well as "capture" of the state by elites and private interests. Firms from countries with below median scores of control of corruption are classified as firms from high corruption countries. Columns 5 and 6 in Table 6 panel A present the results. Investor communication is statistically associated with the valuation of firms from countries with low and high perceived corruption levels. However, this association is more positive for firms from countries with lower levels of perceived corruption, consistent with the idea that perceptions of corruption could 
decrease the effectiveness of communication. In conclusion, the association of investor communication and valuation in my sample is higher for cross-listed firms from countries with lower perceived corruption and smaller cultural distance from the U.S., suggesting that communication is more effective in increasing valuation when these frictions to foreign investment are low.

\section{Legal Tradition}

La Porta, Lopez-de-Silanes, Shleifer, and Vishny (2000) provide evidence that common law countries have more investor protection rights, which could reduce the home bias against firms from common law countries and decrease the potential benefits from communication. Conversely, better investor protections could increase the credibility of voluntary communication activities.

In table 6 panel A columns 7 and 8, I split my sample of cross-listings into firms from countries with common and code legal traditions. The coefficient on investor communication is positive and significant in both subsamples, and although larger for the code-law subgroup, the difference is not statistically significant.

\section{Level of Listing}

The relation between investor communication and valuation may also vary by listing characteristics. I divide my sample between firms that are listed in the U.S. over the counter and on an exchange. Exchange-listed firms are subject to additional disclosure requirements and potentially higher SEC scrutiny. I classify firms that cross-listed in the U.S. through a Level II or Level III ADR program as exchange-listed firms. These firms are required to file an F-6 registration statement and the SEC Form 20-F and to comply with the SEC's other disclosure rules, 
including submission of its annual report, which must be prepared in accordance with U.S. Generally Accepted Accounting Principles (US GAAP) or International Financial Reporting Standards (IFRS). Compliance with Sarbanes-Oxley is also required. These compliances include certifications by management regarding the effectiveness of the company's internal controls over financial reporting and disclosure controls, as well as procedures related to annual reports filed on Form 20-F.

Level I ADRs involve the filing of an F-6 registration statement but allow for exemption under Rule $12 \mathrm{~g} 3-2(\mathrm{~b})^{18}$ from full SEC reporting requirements. For Canadian firms, which do not need an ADR program to cross-list in the U.S., I code firms as exchange-listed if their stock trades at NYSE or NASDAQ according to Compustat. Canadian firms are exempt from U.S. reporting requirements because of the Multijurisdictional Disclosure System. This system essentially acknowledges that disclosure requirements among the two countries are highly comparable.

Columns 1 and 2 in Table 6 panel B present the results. The regression coefficients suggest that the association between communication and firm valuation varies by the level of crosslisting. ${ }^{19}$ Investor communication is statistically and positively associated with the valuation of both groups of firms, but the association is more positive for exchange-listed companies. This could be due to the fact that, as a result of more stringent disclosure requirements, exchange-listed

\footnotetext{
${ }^{18}$ Rule 12g3-2(b) provides foreign private issuers with an exemption from the stringent SEC registration and reporting requirements. In order to gain exemption, a company must publish all material shareholder communication (press releases, annual reports, etc.) on a timely basis, in English on its corporate website. The company's shares or debt instruments must be not already registered under the Exchange Act, and the company must have a "primary trading market" (i.e., it must maintain a listing in one or two jurisdictions outside the U.S. where more than $55 \%$ of the worldwide trading occurs). OTC cross-listed firms are still subject to Rule 10b-5 and the Foreign Corrupt Practices Act.

${ }^{19}$ These results are robust to the exclusion of Canadian firms from the sample.
} 
firms have better information environments and higher accounting quality information, which increases the credibility of voluntary communication. This would be consistent with the findings in Lang et al. (2003b) that suggest that non-U.S. firms cross-listed in U.S. exchanges have higher accounting quality than non-U.S. firms cross-listed over the counter.

\section{Communication of Good and Bad News}

The association between investor communication and valuation may vary according to the type of news being communicated. In order to investigate how my study's results differ in accordance with different news content, I divide my sample into good and bad news firm-years. To determine whether a firm is, on average, communicating good or bad news during the year I use the average composite sentiment (CSS) of the firm-initiated press releases disclosed during the year according to RavenPack. ${ }^{20}$ Only firm-years with at least two firm-initiated press releases in RavenPack are part of these tests.

Table 6 panel B columns 3 and 4 present the results. Investor communication is positively associated with Tobin's q for both good and bad news firm-years and the difference in coefficients is not statistically significant. This result helps to alleviate concerns that investor communication is positively related only to the valuation of cross-listed firms with good news.

\footnotetext{
${ }^{20}$ I follow Bushman et al. (2016) in using the Composite Sentiment Score (CSS) provided by Ravenpack to categorize news stories as positive, neutral or negative. The CSS score ranges from 0 to 100 , with values below 50 indicating negative news, values equal to 50 indicating neutral news and values greater than 50 indicating positive news. The CSS score is the combination of five proprietary sentiment measures that combine textual analysis (identifying emotionally charged words and phrases), expert categorization of topics likely to cause positive or negative short-term market reaction, and an algorithm that ensures agreement among the five sentiment measures. Detailed definitions of these measures are described in Appendix A of Bushman et al. (2016).
} 


\section{Modeling the Decision to Communicate using Instrumental Variables}

Firms in my sample have self-selected to communicate with investors. This may raise the concern that a self-section bias might impact the empirical results. The relation between firms' levels of investor communication and Tobin's q and liquidity could reflect an omitted-variables problem: some unobservable firm attribute may affect a firm's investor communication as well as the firm's value and stock liquidity. In an attempt to alleviate this concern, I model the firms' decision to communicate with investors using an instrumental variables approach.

I model the corporate access decision because this is arguably the most costly investor communication activity in my study and it is strongly correlated with other communication choices, i.e., firms that decide to attend corporate access events in the U.S. also tend to disseminate more press releases in English, hold more conference calls with foreign investors, and disclose more guidance. In addition, costs of attending corporate access events in the U.S. vary for the firms in my sample. For example, it is less costly for a manager located in Canada to travel to the U.S. than it is for a manager located in China. I explore this variation using the availability of direct flights between firms' headquarters and New York City. A good instrument would be related to the level of investor communication a firm decides to have, but uncorrelated with unobservable firm characteristics linked to valuation and liquidity. Direct flight availability is related to managers' time, which is arguably the largest cost of providing corporate access but should not otherwise be related to Tobin's, cost of capital, turnover and bid-ask spreads.

To calculate the availability of direct flights, I follow Giroud (2013) and use data from the T-100 Segment Database from the U.S. Department of Transportation. To get headquarters location information, I use the ADDRESS CITY variable from Datastream. When the address is missing or the country of address and the country of headquarters do not match, I hand-collect 
headquarters' city location from the company's website. I then get latitudes and longitudes for the headquarters' city and for the airports in the T-100 Database, and I code the availability of a direct flight equal to one when there is a direct flight to JFK, La Guardia or Newark leaving from an airport less than 50 miles away from the headquarters' city. I choose New York City airports as my main destination because over $50 \%$ of the U.S. corporate access events in my sample are held in this location. Therefore, I assume that having a direct flight to an NYC airport would impact the cost of meeting with most of U.S. investors and analysts. ${ }^{21}$

I estimate two-stage least square regressions (2SLS) using the availability of direct flights as sources of plausibly exogenous variation in the number of corporate access held in the U.S. as well as in the overall investor communication score. Table 7 panel A presents the results. Within country, within industry, and within year, direct flight availability is significantly and positively associated with cross-listed firms' decision to communicate with investors, using both the communication score and the number of corporate access events in the U.S. The F-statistics for the significance of Direct Flights indicate that the instrument have significant additional explanatory power over the other control variables included. Stock and Yogo's tests reject the null that the instrument is weak.

The second-stage regression results are consistent with my primary findings and indicate that U.S. investor communication is positively associated with the Tobin's q and share turnover of cross-listed firms, and negatively associated with cost of capital and bid-ask spreads. Since the availability of direct flights may be related to the time-varying levels of trade and foreign direct

\footnotetext{
${ }^{21}$ My results are robust, although somewhat weaker, to the inclusion of directs flights between firms' headquarters and any U.S. airport to the Direct Flight variable.
} 
investment in a country, I control for the country-year levels of foreign direct investment and exports and imports to the U.S.

Most firms in my sample do not experience changes in the availability of direct flights during my sample period. As a result, the variation in my regressions comes mostly from differences in direct flight availability across firms within a country. To provide some validity to the claim that firms increase (decrease) communication with U.S. investors when direct flights are initiated (terminated), in panel B I provide univariate evidence of average increases (decreases) in communication for the 53 (29) firms that experienced initiations (terminations) of direct flights during my sample period. The differences between the number of corporate access events in the U.S. and overall investor communication scores pre and post the initiation or termination are both significantly different from zero, indicating that within-firm changes in direct flight availability to NYC are associated with changes in investor communication in the predicted directions.

Although the first and second-stage regressions and univariate results provide evidence consistent with investor communication increasing valuation of cross-listed firms, it is important to note some caveats of direct flights as an instrument in this setting. Direct flights to the U.S. could be a proxy for economic mass of investment and trade between U.S. and other countries. I attempt to control for mass investment and trade by including in the regressions variables such as foreign direct investment and imports and exports between the U.S. and the firm's country. However, these country-level time-varying variables may not fully capture the matching between specific cross-listed firms' capabilities and the U.S. product market needs at that time. 


\section{Communication with U.S. versus Local Investors}

U.S. investors may worry about being in informational disadvantage in relation to local investors when investing in non-U.S. firms. Consistently with this rationale, Bohn and Tesar (1996) and Brennan and Cao (1997) find that U.S. investors chase returns, do not rebalance their international portfolios, and are at an informational disadvantage when they invest abroad. Communication focused on U.S. investors can reduce information asymmetry between local and foreign investors, positively affecting firm valuation and stock liquidity.

In table 8 panel A, I investigate whether the proportion of corporate access events held in the home country versus in the U.S. is associated with the valuation and liquidity of cross-listed firms. For this set of sets, I restrict the sample to firms that held at least one corporate access event in the U.S. and in the home country during the year. Results suggest that cross-listed firms that hold more access events in the home country, in comparison to the U.S., have lower valuations and higher cost of capital. U.S. investors may perceive their information risk to be larger for these firms, leading them to discount these stocks more heavily. Given that the U.S. stock market is the largest in the world, it is plausible that U.S. investors' perceived information disadvantage can significantly affect the valuation of non-U.S. firms.

\section{Falsification Tests}

Assuming that local investors will tend to trade in the home market and U.S. investors will tend to trade in the U.S., I perform falsification regressions of investor communication in the U.S. on liquidity in the home market, and communication in the home market on liquidity in the U.S. Table 8 panel B presents the results. None of the communication coefficients are statistically significant. These results partially mitigate omitted correlated variable concerns regarding the 
firms' decision to communicate with any type of investors, regardless of their nationality. It does not, however, mitigate concerns about firms' reasons to communicate with U.S. investors in particular.

\section{Initiation and Termination of Investor Communication Activities}

In order to shed some light on whether firms experience increases (decreases) in valuation and liquidity when they start (stop) using each of the communication channels in this study, I look at average changes in valuation and liquidity pre and post the initiation and termination of investor communication activities. For this set of tests, I focus on the subsample of firms that started or stopped holding corporate access events in the U.S., conference calls in English, press releases in English or management forecasts during the sample period.

Table 9 presents the results. I find that cross-listed firms experience average increases (decreases) in Tobin's' q when they start (stop) participating in corporate access events in the U.S. and disseminating press releases in English. They also experience decreases (increases) in cost of capital when they start (stop) holding conference calls in English and disseminating English press releases. Turnover in the U.S. increases (decreases) when cross-listed firms start (stop) holding conference calls in English and disclosing management forecasts. Bid-ask spreads in the U.S. decreases (increases) when firms start (stop) participating in corporate access events in the U.S. and disseminating press releases in English.

Overall, evidence from these tests suggests that the initiation of investor communication activities focused on U.S. investors are positively related to cross-listed firms' valuation and liquidity in the U.S. 


\section{Valuation Premium of Cross-listed Firms Relative to Non-cross-listed Firm}

Most papers in the cross-listing literature investigate the valuation premium of cross-listed firms relative to non-cross-listed firms. The idea is that absent cross-listing, both groups of firms should be valued similarly. To maintain consistency with these studies, in my next series of tests I include a matched sample of non-cross-listed firms. Firm-years are matched based on country, industry, and closeness in size, measured by total assets in U.S. dollars. In order to reduce the number of cross-listed firms excluded due to missing matches, I match cross-listed and non-crosslisted firms with repetition.

I start by investigating how the valuation premium of cross-listed relative to non-crosslisted firms varies after cross-listing, controlling for investor communication choices. Table 10 panel A presents the results of regressions of Tobin's q on XLISTED, an indicator variable equal to one if the firm is a cross-listed firm; investor communication dummies; the investor communication score and a set of control variables in the years after cross-listing. The coefficient on XLISTED in column 1 indicates that cross-listed firms are valued at a premium relative to noncross-listed firms from the same country and industry. This finding is consistent with the pervasive evidence in the cross-listing literature (Karolyi 1998, 2006).

Columns 2 to 6 in Table 10 panel A add dummies for investor communication choices, and column 7 adds the investor communication score variable. The control variables have the same magnitudes, signs, and statistical significance. However, the estimated valuation premium of cross-listed firms relative to non-cross-listed firms is reduced around 51\% after I control for communication choice dummies. For instance, the estimated coefficient on XLISTED goes from 0.121 to 0.059 after I control for the decision to provide corporate access, to 0.075 after I control for the decision to provide a conference call, and to 0.059 after I control for the decision to 
disseminate a press release. Column 6 presents the result from a regression including all communication choices, and column 7 presents the result including the investor communication score. The coefficient on XLISTED drops to 0.02 and is no longer statistically significant. Coefficients on the dummies for corporate access and press releases remain positive and statistically significant. The change in the magnitude and statistical significance of XLISTED suggests that controlling for communication choices explains much of the unexplained valuation premium. Put differently, it appears that a significant portion of the premium in the valuation of cross-listed companies is attributed to increased communication.

In order to further investigate whether cross-listed firms that do not communicate with investors are valued at a premium relative to non-cross-listed firms, I classify firms using at least one of the four communication channels during the year as communicating firms. I then partition the sample into four comparison groups: i) cross-listed communicating firms and non-cross-listed non-communicating firms, ii) cross-listed communicating firms and non-cross-listed communicating firms, iii) cross-listed non-communicating firms and non-cross-listed noncommunicating firms, and iv) cross-listed non-communicating firms and non-cross-listed communicating firms. Table 10 panel B presents the results.

Findings suggest that cross-listed firms that do not communicate with investors are not valued at a premium relative to non-cross-listed firms. When both groups of firms communicate with investors, cross-listed firms are still valued at a premium relative to non-cross-listed firms, which suggests that cross-listing does benefit firms as long as they communicate with investors. In summary, these results suggest that when comparing the valuation of cross-listed firms relative to non-cross-listed firms, researchers should be aware of and try to control for differences in the investor communication practices of these firms. 


\section{Product Market Benefits of Cross-Listing and Investor Communication}

Survey evidence suggests that some managers cross-list their companies' shares for product-market reasons (Mittoo 1992; Bancel and Mittoo 2001; King and Mittoo 2007). Crosslistings can increase the firms' international visibility and help the product identification and the marketing efforts in foreign markets. Cross-listing may also help to improve the relationship with the government and financial community of the foreign country of listing (Mittoo 1992).

In untabulated tests, I find that cross-listed firms' international sales increase after crosslisting and that this increase is significantly larger for cross-listed firms that communicate more with U.S. investors. In unreported cross-sectional tests, I also find that the association between investor communication and valuation is stronger for cross-listed firms with a higher proportion of international to total sales. These findings suggest that cross-listed firms with more foreign sales benefit more from communication with U.S. investors. Overall, these preliminary results suggest that investor communication can be a channel through which firms achieve not only capital market but also product market's benefits of cross-listing. 


\section{CHAPTER V}

\section{Conclusion}

In this study, I investigate whether communication with U.S. investors helps non-U.S. firms maintain the capital market benefits of U.S. listings. I argue that foreign firms that do not meet the expectations of U.S. investors and analysts regarding the frequency and form of corporate communication may not be able to keep the benefits of a U.S. listing. I posit that the management communication strategies of non-U.S. firms focused on U.S. audiences are related to cross-listed firms' success in maintaining higher levels of liquidity and valuation post cross-listing.

This study demonstrates that investor communication mitigates the post cross-listing decline in valuation documented by prior studies. Communication choices also explain variation in the valuation, cost of capital, and stock liquidity of cross-listed firms from the same country in the long run. In addition, firms that cross-list but do not communicate with U.S. investors are more likely to delist from the U.S. in subsequent years. These findings are robust to concerns about potential endogeneity, as I model investor communication choices using the availability of direct flights between headquarters and the U.S.

Lastly, I compare the valuation of cross-listed and non-cross-listed firms. My findings suggest that a significant portion of the cross-listing valuation premium is associated with the investor communication practices of these firms. Firms that cross-list in the U.S. but do not communicate with U.S. investors are not valued at a premium relative to non-cross-listed firms from the same country. In general, my empirical findings indicate that investor communication is 
an important condition for firms to achieve the long-run benefits of cross-listing. My results also suggest that investor communication is an important factor in explaining the valuation of crosslisted firms, and it should be taken into consideration in analyzing the valuation premium of crosslisted firms relative to non-cross-listed firms.

Prior literature suggests that success in building a larger U.S. investor base, media coverage, and analyst following is related to cross-listing valuation effects. My findings extend and elaborate on existing research, accounting specifically for the role of communication choices in U.S. cross-listing outcomes.

My measures of communication take into account the choice of channels and their frequency but not the quality of communication. Thus, future research could use textual analysis to measure the rigor and responsiveness with which managers of cross-listed firms answer questions from analysts in conference call transcripts. Responsiveness could then be used as a more granular measure of the quality of the communication efforts of cross-listed firms with U.S. analysts and investors. 
FIGURES 
Figure 1 - Mean Tobin's q around Cross-Listing for High and Low Communication Firms

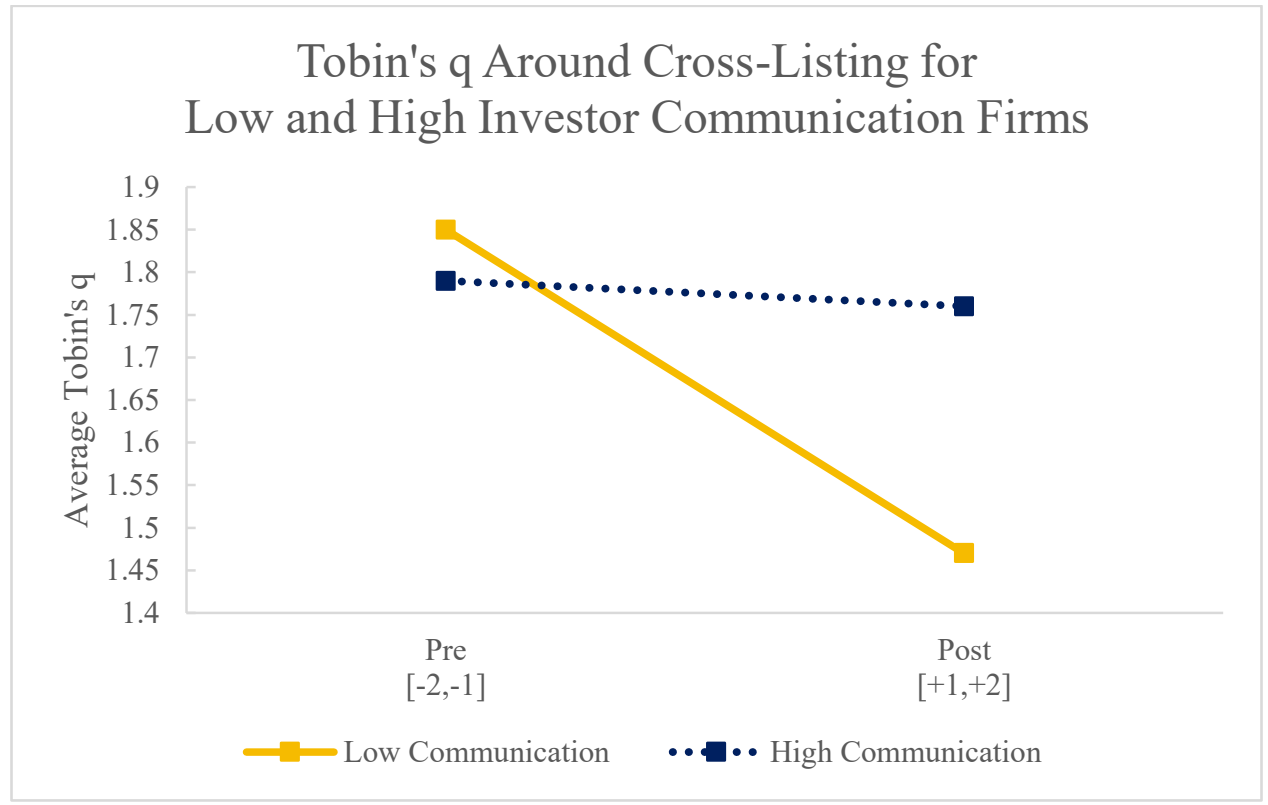

Figure 1 presents the average Tobin's q around cross-listing for firms in the lower and upper quartiles of investor communication. Year 0 is the cross-listing year. 
TABLES 


\section{Table 1 - Sample Selection}

\begin{tabular}{|c|c|c|}
\hline & Firm-years & Firms \\
\hline Sample of sponsored cross-listings between 2006-2013 according to Depositary Banks and SEC filings & 7,739 & 959 \\
\hline $\begin{array}{l}\text { Firm-years without necessary data in Datastream (total assets, liabilities, non-negative shareholders' equity, sales, net income, } \\
\text { and market value of equity) }\end{array}$ & $(4,422)$ & $(402)$ \\
\hline Subtotal & 3,317 & 557 \\
\hline $\begin{array}{l}\text { Older cross-listings from the same country, from the same industry and of similar size with necessary data in Datastream } \\
\text { (with replacement) }\end{array}$ & 1,265 & 247 \\
\hline $\begin{array}{l}\text { Non-cross-listed firm-years from the same country, from the same industry and of similar size with necessary data in Datastream } \\
\text { (with replacement) }\end{array}$ & 2,301 & 423 \\
\hline Final sample & 6,883 & 1,227 \\
\hline
\end{tabular}

Table 1 details the sample selection process and is discussed in section 3.1. The list of cross-listed firms was obtained from Edgar 20-F and 6-K filings and from the Bank of New York, Citibank and JP Morgan lists of ADRs. Cross-listing dates are collected from the depositary banks' lists and from CRSP. Financial and price data are from Datastream. Cross-listings from 2006 to 2013 are matched with replacement to a sample of non-cross-listed (domestic) firm-years from the same country, from the same industry and of similar size, measured by total assets in U.S. dollars, and to a sample of firms cross-listed prior to 2006 from the same country, from the same industry, and of similar size. 
Table 2 - Descriptive Statistics

PANEL A: Summary Statistics

\begin{tabular}{|c|c|c|c|c|c|c|c|c|c|c|c|c|c|c|}
\hline \multirow{3}{*}{$\begin{array}{l}\text { Variable } \\
\text { Corporate Access US }\end{array}$} & \multicolumn{2}{|c|}{$\begin{array}{c}\text { 2006-2013 } \\
\text { Cross-listings }\end{array}$} & \multicolumn{2}{|c|}{$\begin{array}{l}\text { Prior to } 2006 \\
\text { Cross-listings }\end{array}$} & \multirow{2}{*}{\multicolumn{2}{|c|}{$\begin{array}{c}\text { Mean } \\
\text { Difference } \\
\text { t-test }\end{array}$}} & \multirow{2}{*}{\multicolumn{2}{|c|}{$\begin{array}{c}\text { Median } \\
\text { Difference } \\
\text { Sign-rank Test }\end{array}$}} & \multicolumn{2}{|c|}{$\begin{array}{l}\text { Non-cross-listed } \\
\text { Firms }\end{array}$} & \multirow{2}{*}{\multicolumn{2}{|c|}{$\begin{array}{c}\text { Mean } \\
\text { Difference } \\
\text { t-test }\end{array}$}} & \multirow{2}{*}{\multicolumn{2}{|c|}{$\begin{array}{c}\text { Median } \\
\text { Difference } \\
\text { Sign-rank } \\
\text { Test }\end{array}$}} \\
\hline & \multirow{2}{*}{$\frac{\text { Mean }}{0.645}$} & \multirow{2}{*}{$\frac{\text { Median }}{0.000}$} & \multirow{2}{*}{$\frac{\text { Mean }}{0.401}$} & \multirow{2}{*}{$\frac{\text { Median }}{0.000}$} & & & & & Mean & Median & & & & \\
\hline & & & & & -0.244 & $* * *$ & 0.000 & & 0.068 & 0.000 & -0.576 & $* * *$ & 0.000 & \\
\hline DCorporate Access US & 0.232 & 0.000 & 0.145 & 0.000 & -0.087 & $* * *$ & 0.000 & & 0.032 & 0.000 & -0.200 & $* * *$ & 0.000 & \\
\hline Conference Calls & 1.628 & 1.000 & 1.345 & 0.000 & -0.283 & $* * *$ & -1.000 & $* * *$ & 0.425 & 0.000 & -1.203 & $* * *$ & -1.000 & $* * *$ \\
\hline DConference Calls & 0.525 & 1.000 & 0.413 & 0.000 & -0.112 & $* * *$ & -1.000 & $* * *$ & 0.165 & 0.000 & -0.360 & $* * *$ & -1.000 & $* * *$ \\
\hline Nr. of Press Releases & 14.371 & 1.000 & 18.128 & 0.000 & 3.757 & $* *$ & -1.000 & $* *$ & 2.100 & 0.000 & -12.271 & $* * *$ & -1.000 & $* * *$ \\
\hline DPress Release & 0.553 & 1.000 & 0.489 & 0.000 & -0.064 & $* * *$ & -1.000 & $* * *$ & 0.194 & 0.000 & -0.359 & $* * *$ & -1.000 & $* * *$ \\
\hline Management Forecast & 0.744 & 0.000 & 0.669 & 0.000 & -0.076 & & 0.000 & & 0.049 & 0.000 & -0.696 & $* * *$ & 0.000 & \\
\hline DManagement Forecast & 0.228 & 0.000 & 0.186 & 0.000 & -0.042 & $* * *$ & 0.000 & & 0.031 & 0.000 & -0.197 & $* * *$ & 0.000 & \\
\hline Nr. US Inst. Investors & 11.375 & 0.000 & 20.113 & 0.000 & 8.738 & $* * *$ & 0.000 & & 2.109 & 0.000 & -9.266 & $* * *$ & 0.000 & \\
\hline Perc. US Instit. & 0.023 & 0.000 & 0.028 & 0.000 & 0.005 & $*$ & 0.000 & & 0.006 & 0.000 & -0.017 & $* * *$ & 0.000 & \\
\hline Tobin's q & 1.641 & 1.258 & 1.550 & 1.180 & -0.091 & $* * *$ & -0.078 & $* * *$ & 1.515 & 1.174 & -0.126 & $* * *$ & -0.084 & $* * *$ \\
\hline Turnover in the U.S. & 0.630 & 0.011 & 0.452 & 0.034 & -0.178 & $* * *$ & 0.023 & $* *$ & NA & NA & NA & & NA & \\
\hline Avg. Spread in the U.S. & 0.017 & 0.007 & 0.013 & 0.007 & -0.004 & $* *$ & 0.000 & & NA & NA & NA & & NA & \\
\hline Log of Assets (in USD) & 13.605 & 13.681 & 13.531 & 13.655 & -0.074 & & -0.026 & & 12.554 & 12.617 & -1.051 & $* * *$ & -1.063 & $* * *$ \\
\hline Sales Growth & 0.272 & 0.107 & 0.237 & 0.089 & -0.035 & & -0.018 & $* * *$ & 0.185 & 0.078 & -0.087 & $* * *$ & -0.029 & $* * *$ \\
\hline ROA & -0.040 & 0.025 & -0.041 & 0.022 & 0.000 & & -0.002 & & -0.025 & 0.027 & 0.016 & $* *$ & 0.002 & \\
\hline Leverage & 0.480 & 0.460 & 0.498 & 0.485 & 0.017 & $* *$ & 0.026 & $* *$ & 0.497 & 0.485 & 0.017 & $* * *$ & 0.025 & $* * *$ \\
\hline Analyst Following & 9.297 & 6.000 & 6.680 & 3.000 & -2.617 & $* * *$ & -3.000 & $* * *$ & 3.755 & 1.000 & -5.542 & $* * *$ & -5.000 & $* * *$ \\
\hline Local Index Participant & 0.389 & 0.000 & 0.344 & 0.000 & -0.045 & $* *$ & 0.000 & & 0.254 & 0.000 & -0.135 & $* * *$ & 0.000 & \\
\hline Exchange Cross-listing & 0.235 & 0.000 & 0.263 & 0.000 & 0.029 & & 0.000 & & NA & NA & NA & & NA & \\
\hline
\end{tabular}

Panel A provides descriptive statistics for the samples of 2006-2013 cross-listings, matched prior to 2006 cross-listings and matched non-cross-listed firm-years. All variables are defined in Appendix A. Continuous variables are winsorized at the 1 st and 99 th percentiles. Significance at the $10 \%, 5 \%$ and $1 \%$ levels for two-sided tests is denoted by $* * *$, and ***, respectively. 


\section{Table 2 - Descriptive Statistics}

PANEL B: Observations by Country

\begin{tabular}{|c|c|c|}
\hline Country & "Firm-years & $\%$ \\
\hline Argentina & 105 & $1.5 \%$ \\
\hline Australia & 1,003 & $14.6 \%$ \\
\hline Belgium & 48 & $0.7 \%$ \\
\hline Brazil & 496 & $7.2 \%$ \\
\hline Canada & 551 & $8.0 \%$ \\
\hline Chile & 5 & $0.1 \%$ \\
\hline China & 845 & $12.3 \%$ \\
\hline Colombia & 42 & $0.6 \%$ \\
\hline Cyprus & 7 & $0.1 \%$ \\
\hline Denmark & 87 & $1.3 \%$ \\
\hline Egypt & 22 & $0.3 \%$ \\
\hline France & 241 & $3.5 \%$ \\
\hline Germany & 258 & $3.8 \%$ \\
\hline Greece & 84 & $1.2 \%$ \\
\hline Hong Kong & 285 & $4.1 \%$ \\
\hline India & 237 & $3.4 \%$ \\
\hline Ireland & 36 & $0.5 \%$ \\
\hline Israel & 207 & $3.0 \%$ \\
\hline Italy & 45 & $0.7 \%$ \\
\hline Japan & 401 & $5.8 \%$ \\
\hline Kuwait & 18 & $0.3 \%$ \\
\hline Luxembourg & 8 & $0.1 \%$ \\
\hline Malaysia & 45 & $0.7 \%$ \\
\hline Mexico & 45 & $0.7 \%$ \\
\hline Netherlands & 69 & $1.0 \%$ \\
\hline New Zealand & 55 & $0.8 \%$ \\
\hline Norway & 71 & $1.0 \%$ \\
\hline Pakistan & 93 & $1.4 \%$ \\
\hline Peru & 15 & $0.2 \%$ \\
\hline Philippines & 47 & $0.7 \%$ \\
\hline Russia & 349 & $5.1 \%$ \\
\hline Singapore & 26 & $0.4 \%$ \\
\hline South Africa & 69 & $1.0 \%$ \\
\hline South Korea & 113 & $1.6 \%$ \\
\hline Spain & 27 & $0.4 \%$ \\
\hline Sweden & 78 & $1.1 \%$ \\
\hline Switzerland & 36 & $0.5 \%$ \\
\hline Taiwan & 80 & $1.2 \%$ \\
\hline United Arab Emirates & 18 & $0.3 \%$ \\
\hline United Kingdom & 616 & $9.0 \%$ \\
\hline Total & 6,883 & $100 \%$ \\
\hline
\end{tabular}

Panel B provides the number of firm-year observations per country for the full sample of cross-listed and non-cross-listed firms. 
Table 2 - Descriptive Statistics

PANEL C: Correlation Matrix

\begin{tabular}{|c|c|c|c|c|c|c|c|c|c|c|c|c|c|c|c|c|c|c|}
\hline & Variables & (1) & $(2)$ & (3) & (4) & (5) & $(6)$ & (7) & $(8)$ & (9) & $(10)$ & (11) & (12) & (13) & (14) & $(15)$ & (16) & $(17)$ \\
\hline (1) & Cross-listed & 1 & 0.23 & 0.11 & 0.33 & 0.25 & 0.34 & 0.22 & 0.23 & 0.26 & 0.04 & 0.01 & -0.06 & 0.20 & 0.04 & -0.02 & -0.02 & 0.31 \\
\hline (2) & Corp. Access US & 0.18 & 1 & 0.33 & 0.45 & 0.34 & 0.35 & 0.17 & 0.17 & 0.25 & 0.11 & 0.23 & -0.10 & 0.08 & 0.04 & 0.01 & -0.05 & 0.29 \\
\hline (3) & Corp. Access Home & 0.09 & 0.37 & 1 & 0.29 & 0.20 & 0.20 & 0.10 & 0.10 & 0.24 & 0.05 & -0.01 & -0.11 & 0.15 & -0.01 & 0.04 & 0.01 & 0.10 \\
\hline (4) & Conference Calls & 0.32 & 0.38 & 0.25 & 1 & 0.40 & 0.50 & 0.23 & 0.23 & 0.44 & 0.04 & 0.34 & -0.09 & 0.35 & 0.02 & 0.09 & 0.12 & 0.29 \\
\hline (5) & Manag. Forecast & 0.20 & 0.27 & 0.09 & 0.32 & 1 & 0.39 & 0.15 & 0.15 & 0.36 & 0.03 & 0.41 & -0.10 & 0.17 & 0.02 & 0.07 & -0.00 & 0.30 \\
\hline (6) & Log Press Releases & 0.31 & 0.29 & 0.19 & 0.46 & 0.34 & 1 & 0.25 & 0.25 & 0.37 & 0.07 & 0.33 & -0.10 & 0.32 & 0.01 & 0.06 & 0.10 & 0.33 \\
\hline (7) & Perc. Institutions & 0.10 & 0.17 & 0.10 & 0.19 & 0.16 & 0.21 & 1 & 1.00 & 0.15 & 0.02 & 0.27 & -0.12 & 0.21 & 0.02 & 0.06 & 0.01 & 0.30 \\
\hline (8) & \# Institutions & 0.13 & 0.16 & 0.12 & 0.19 & 0.10 & 0.27 & 0.69 & 1 & 0.15 & 0.03 & 0.27 & -0.14 & 0.22 & 0.02 & 0.07 & 0.02 & 0.30 \\
\hline (9) & \# Analysts & 0.26 & 0.20 & 0.22 & 0.37 & 0.26 & 0.40 & 0.15 & 0.16 & 1 & 0.13 & 0.11 & -0.51 & 0.56 & 0.09 & 0.28 & 0.16 & 0.13 \\
\hline (10) & Tobin's q & 0.04 & 0.10 & 0.02 & -0.01 & -0.00 & 0.03 & 0.04 & 0.04 & 0.04 & 1 & 0.05 & -0.27 & -0.14 & 0.07 & 0.17 & -0.01 & 0.02 \\
\hline (11) & Turnover U.S. & $\cdot$ & 0.09 & -0.04 & 0.21 & 0.41 & 0.25 & 0.20 & 0.13 & 0.11 & 0.07 & 1 & -0.28 & -0.05 & 0.05 & 0.06 & -0.05 & 0.64 \\
\hline (12) & Avg. Spread U.S. & . & -0.09 & -0.04 & -0.15 & -0.06 & -0.15 & -0.14 & -0.21 & -0.32 & -0.13 & -0.21 & 1 & -0.54 & -0.16 & -0.36 & -0.18 & -0.07 \\
\hline (13) & Log of Assets & 0.20 & 0.07 & 0.16 & 0.33 & 0.10 & 0.36 & 0.10 & 0.25 & 0.56 & -0.23 & -0.07 & -0.36 & 1 & 0.06 & 0.29 & 0.43 & 0.10 \\
\hline (14) & Sales Growth & 0.05 & 0.01 & -0.03 & -0.02 & -0.01 & 0.00 & 0.01 & 0.00 & 0.02 & 0.02 & 0.06 & -0.05 & 0.02 & 1 & 0.19 & 0.01 & 0.02 \\
\hline (15) & ROA & -0.03 & 0.02 & 0.05 & 0.11 & 0.07 & 0.07 & 0.03 & 0.07 & 0.20 & -0.19 & 0.07 & -0.24 & 0.41 & 0.04 & 1 & -0.06 & 0.01 \\
\hline (16) & Leverage & -0.02 & -0.06 & 0.00 & 0.08 & -0.04 & 0.11 & 0.01 & 0.04 & 0.14 & -0.00 & -0.01 & -0.13 & 0.32 & -0.03 & -0.09 & 1 & -0.03 \\
\hline (17) & Exchange Xlisting & 0.31 & 0.24 & 0.08 & 0.31 & 0.32 & 0.35 & 0.28 & 0.32 & 0.13 & 0.02 & 0.31 & -0.04 & 0.12 & 0.01 & 0.05 & -0.03 & 1 \\
\hline
\end{tabular}

Panel C provides correlations for the pooled sample of cross-listed and non-cross-listed firms. Pearson (Spearman) correlations are presented below (above) the diagonal. Correlations

in bold are significant at the 5\% level or better. All variables are defined in Appendix I. Continuous variables are winsorized at the 1st and 99th percentiles. 


\section{Table 3 - Investor Communication Choices}

\section{PANEL A: Characteristics of Cross-listed Firm-years by Investor Communication Choices}

\begin{tabular}{|c|c|c|c|c|c|c|}
\hline & $\begin{array}{l}\text { Not using any of } \\
\text { the channels } \\
(\mathrm{N}=1,444)\end{array}$ & $\begin{array}{c}\text { Attending access } \\
\text { events } \\
(\mathrm{N}=953)\end{array}$ & $\begin{array}{c}\text { Holding } \\
\text { conference calls } \\
(\mathrm{N}=2,263)\end{array}$ & $\begin{array}{c}\text { Disclosing } \\
\text { press releases } \\
(\mathrm{N}=2,453)\end{array}$ & $\begin{array}{c}\text { Disclosing } \\
\text { management forecasts } \\
(\mathrm{N}=991)\end{array}$ & $\begin{array}{c}\text { Using all four } \\
\text { channels } \\
(\mathrm{N}=364)\end{array}$ \\
\hline Variable & Mean & Mean & Mean & Mean & Mean & Mean \\
\hline Corporate Access US & 0.00 & 2.78 & 1.05 & 0.90 & 1.38 & 3.29 \\
\hline DCorporate Access US & 0.00 & 1.00 & 0.36 & 0.31 & 0.43 & 1.00 \\
\hline Conference Calls & 0.00 & 2.99 & 3.14 & 2.22 & 2.73 & 3.60 \\
\hline DConference Call & 0.00 & 0.86 & 1.00 & 0.70 & 0.81 & 1.00 \\
\hline Press Releases & 0.00 & 30.27 & 26.71 & 28.78 & 28.38 & 35.99 \\
\hline DPress Release & 0.00 & 0.80 & 0.75 & 1.00 & 0.82 & 1.00 \\
\hline Management Forecasts & 0.00 & 1.62 & 1.15 & 1.13 & 3.35 & 3.67 \\
\hline DManagement Forecast & 0.00 & 0.44 & 0.35 & 0.33 & 1.00 & 1.00 \\
\hline Log of Assets (in USD) & 12.37 & 13.83 & 14.51 & 14.19 & 14.29 & 14.19 \\
\hline Nr. US Inst. Investors & 2.73 & 27.92 & 21.46 & 20.02 & 22.18 & 27.32 \\
\hline Analyst Following & 4.33 & 11.72 & 11.84 & 11.09 & 14.70 & 15.80 \\
\hline Sales Growth & 0.27 & 0.24 & 0.22 & 0.26 & 0.19 & 0.19 \\
\hline ROA & -0.10 & -0.02 & 0.01 & -0.01 & 0.02 & 0.02 \\
\hline Leverage & 0.43 & 0.46 & 0.53 & 0.50 & 0.48 & 0.45 \\
\hline
\end{tabular}

PANEL B: Factor Analysis of Investor Communication Choices of Cross-Listed Firms (Investor Communication Score)

\begin{tabular}{lcccc} 
Factor & Eigenvalue & Difference & Proportion & Cumulative \\
\hline Factor1 & 1.955 & 1.179 & 0.489 & 0.489 \\
Factor2 & 0.776 & 0.052 & 0.194 & 0.683 \\
Factor3 & 0.724 & 0.178 & 0.181 & 0.864 \\
Factor4 & 0.546 &. & 0.136 & 1.000 \\
\hline
\end{tabular}

\begin{tabular}{lccc} 
Variable & Factor 1 & Uniqueness & Scoring Coefficients \\
\hline Access US & 0.651 & 0.577 & 0.33263 \\
Conference Calls & 0.767 & 0.412 & 0.39192 \\
Log Number PR & 0.734 & 0.461 & 0.37534 \\
Management Forecasts & 0.636 & 0.596 & 0.32497 \\
\hline
\end{tabular}

Panel A presents the average characteristics of cross-listed firm-years using each of the investor communication channels. Means for the investor communication dummies show the proportion of firm-years that used both of the channels. Panel B presents the results of factor analysis using the four communication variables and the scoring coefficients used to construct the investor communication score. 


\section{Table 3 - Investor Communication Choices}

PANEL C: Determinants of the Decision of Cross-Listed Firms to Communicate with U.S. Investors

\begin{tabular}{|c|c|c|c|}
\hline & \multirow[b]{2}{*}{ Prediction } & \multicolumn{2}{|c|}{ Inv. Comm. Score } \\
\hline & & (1) & (2) \\
\hline Corporate Access Home & + & $\begin{array}{l}0.228 * * * \\
(0.026)\end{array}$ & $\begin{array}{l}0.234 * * * \\
(0.027)\end{array}$ \\
\hline Equity Issuance & + & $\begin{array}{l}0.169^{* * *} \\
(0.037)\end{array}$ & $\begin{array}{l}0.189 * * * \\
(0.040)\end{array}$ \\
\hline Exchange Cross-Listing & + & $\begin{array}{l}0.416^{* * *} \\
(0.094)\end{array}$ & $\begin{array}{l}0.663 * * * \\
(0.072)\end{array}$ \\
\hline IFRS & + & $\begin{array}{l}0.078 * * \\
(0.039)\end{array}$ & $\begin{array}{l}0.345^{* * * *} \\
(0.060)\end{array}$ \\
\hline International Sales Ratio & + & $\begin{array}{l}0.134 * \\
(0.079)\end{array}$ & $\begin{array}{l}0.220 * * * \\
(0.078)\end{array}$ \\
\hline Log of Assets & + & $\begin{array}{l}0.112 * * * \\
(0.016)\end{array}$ & $\begin{array}{l}0.108^{* * *} \\
(0.018)\end{array}$ \\
\hline Lead Asset Growth & + & $\begin{array}{c}0.007 \\
(0.010)\end{array}$ & $\begin{array}{l}0.007 \\
(0.010)\end{array}$ \\
\hline Lead Earnings Growth & + & $\begin{array}{l}0.004 * \\
(0.003)\end{array}$ & $\begin{array}{l}0.002 \\
(0.003)\end{array}$ \\
\hline ROA & + & $\begin{array}{l}-0.068 \\
(0.054)\end{array}$ & $\begin{array}{l}0.032 \\
(0.061)\end{array}$ \\
\hline Leverage & - & $\begin{array}{l}-0.016 \\
(0.095)\end{array}$ & $\begin{array}{l}0.007 \\
(0.097)\end{array}$ \\
\hline High Cultural Distance & - & & $\begin{array}{l}-0.243 * * * \\
(0.081)\end{array}$ \\
\hline English & + & & $\begin{array}{l}0.191 * \\
(0.101)\end{array}$ \\
\hline High Corruption & $+/-$ & & $\begin{array}{l}0.234 * * * \\
(0.054)\end{array}$ \\
\hline Common Law & $+/-$ & & $\begin{array}{l}-0.463 * * * \\
(0.090)\end{array}$ \\
\hline Constant & & $\begin{array}{l}-2.862 * * * \\
(0.216)\end{array}$ & $\begin{array}{l}-2.771 * * * \\
(0.282)\end{array}$ \\
\hline Fixed Effects & & $\begin{array}{c}\text { Country, } \\
\text { Industry, } \\
\text { Year }\end{array}$ & $\begin{array}{c}\text { Industry, } \\
\text { Year }\end{array}$ \\
\hline $\mathrm{N}$ & & 3,661 & 3,661 \\
\hline R-squared & & 0.564 & 0.448 \\
\hline
\end{tabular}

Panel A presents results for the regressions of the investor communication score on firm and country characteristics for the sample of cross-listed firms. Robust standard errors clustered by firm are presented in parentheses. *, **, and $* * *$ denote statistical significance at $10 \%, 5 \%$ and $1 \%$, respectively. Variables are described in Appendix I. Continuous variables are winsorized at the 1 st and 99 th percentile. 
Table 4 - Capital Market Benefits and Investor Communication Around Cross-Listing

PANEL A: Investor Communication and the Decline in Valuation Post Cross-Listing

\begin{tabular}{|c|c|c|c|c|c|c|c|c|c|c|}
\hline & \multirow[b]{3}{*}{ Pred. } & \multicolumn{3}{|c|}{ Tobin's q } & \multicolumn{3}{|c|}{ Cost of Capital } & \multicolumn{3}{|c|}{ " Annual Stock Returns } \\
\hline & & \multicolumn{2}{|c|}{$\begin{array}{l}\text { Full Sample of } \\
2006-2013 \\
\text { Cross-Listings }\end{array}$} & \multirow{2}{*}{$\begin{array}{l}\text { Excluding Firms } \\
\text { Issuing Shares in } \\
\text { the U.S. at the time } \\
\text { of Cross-Listing } \\
\text { (3) }\end{array}$} & \multicolumn{2}{|c|}{$\begin{array}{l}\text { Full Sample of } \\
2006-2013 \\
\text { Cross-Listings }\end{array}$} & \multirow{2}{*}{$\begin{array}{l}\text { Excluding Firms } \\
\text { Issuing Shares in } \\
\text { the U.S. at the time } \\
\text { of Cross-Listing } \\
(6)\end{array}$} & \multicolumn{2}{|c|}{$\begin{array}{l}\text { Full Sample of } \\
2006-2013 \\
\text { Cross-Listings }\end{array}$} & \multirow{2}{*}{$\begin{array}{l}\text { Excluding Firms } \\
\text { Issuing Shares in } \\
\text { the U.S. at the time } \\
\text { of Cross-Listing } \\
\text { (9) }\end{array}$} \\
\hline & & (1) & (2) & & (4) & (5) & & (7) & (8) & \\
\hline Post &,,-+- & $\begin{array}{l}\mathbf{- 0 . 0 8 4 *} \\
(0.054)\end{array}$ & $\begin{array}{l}\mathbf{- 0 . 1 1 3 * *} \\
(0.061)\end{array}$ & $\begin{array}{l}\mathbf{- 0 . 1 4 9 * *} \\
(0.068)\end{array}$ & $\begin{array}{l}-0.006 \\
(0.008)\end{array}$ & $\begin{array}{l}0.002 \\
(0.009)\end{array}$ & $\begin{array}{c}0.005 \\
(0.010)\end{array}$ & $\begin{array}{l}\mathbf{- 0 . 1 1 7 * * *} \\
(0.042)\end{array}$ & $\begin{array}{l}\mathbf{- 0 . 1 5 5 * * *} \\
(0.046)\end{array}$ & $\begin{array}{l}-\mathbf{- 0 . 1 6 7 * * *} \\
(0.052)\end{array}$ \\
\hline $\begin{array}{l}\text { Post } \times \text { High } \\
\text { Comm. }\end{array}$ &,,+-+ & & $\begin{array}{l}\text { 0.205** } \\
(0.089)\end{array}$ & $\begin{array}{l}\mathbf{0 . 2 1 4} * * \\
(0.097)\end{array}$ & & $\begin{array}{l}-\mathbf{0 . 0 2 6} * * * \\
(0.010)\end{array}$ & $\begin{array}{l}-\mathbf{0 . 0 2 6} * * * \\
(0.011)\end{array}$ & & $\begin{array}{l}\mathbf{0 . 1 6 8} * * * \\
(0.066)\end{array}$ & $\begin{array}{l}\mathbf{0 . 1 6 1} * * * \\
(0.068)\end{array}$ \\
\hline $\begin{array}{l}\text { High } \\
\text { Comm. }\end{array}$ & & & $\begin{array}{l}0.004 \\
(0.081)\end{array}$ & $\begin{array}{l}-0.020 \\
(0.083)\end{array}$ & & $\begin{array}{l}0.011 \\
(0.009)\end{array}$ & $\begin{array}{l}0.015 * * \\
(0.009)\end{array}$ & & $\begin{array}{l}-0.143 * * * \\
(0.058)\end{array}$ & $\begin{array}{l}-0.117 * * \\
(0.058)\end{array}$ \\
\hline $\begin{array}{l}\text { Equity } \\
\text { Issuance }\end{array}$ & & $\begin{array}{l}0.223 * * * \\
(0.036)\end{array}$ & $\begin{array}{l}0.173 * * * \\
(0.036)\end{array}$ & $\begin{array}{l}0.153 * * * \\
(0.045)\end{array}$ & $\begin{array}{l}-0.008 \\
(0.006)\end{array}$ & $\begin{array}{l}-0.007 \\
(0.006)\end{array}$ & $\begin{array}{l}-0.001 \\
(0.007)\end{array}$ & $\begin{array}{l}0.189 * * * \\
(0.030)\end{array}$ & $\begin{array}{l}0.188^{* * *} \\
(0.030)\end{array}$ & $\begin{array}{l}0.194 * * * \\
(0.034)\end{array}$ \\
\hline $\begin{array}{l}\text { International } \\
\text { Sales }\end{array}$ & & $\begin{array}{l}0.173 * * * \\
(0.061)\end{array}$ & $\begin{array}{l}0.210^{* * *} \\
(0.061)\end{array}$ & $\begin{array}{l}0.221 * * * \\
(0.067)\end{array}$ & $\begin{array}{l}0.021 * * \\
(0.010)\end{array}$ & $\begin{array}{l}0.021 * * \\
(0.010)\end{array}$ & $\begin{array}{l}0.026^{* *} \\
(0.011)\end{array}$ & $\begin{array}{l}0.071 \\
(0.048)\end{array}$ & $\begin{array}{l}0.073 \\
(0.048)\end{array}$ & $\begin{array}{l}0.039 \\
(0.050)\end{array}$ \\
\hline IFRS & & $\begin{array}{l}-0.073 \\
(0.068)\end{array}$ & $\begin{array}{l}-0.083 \\
(0.065)\end{array}$ & $\begin{array}{l}-0.026 \\
(0.081)\end{array}$ & $\begin{array}{l}-0.028^{* *} \\
(0.013)\end{array}$ & $\begin{array}{l}-0.027 * * \\
(0.013)\end{array}$ & $\begin{array}{l}-0.038^{* *} \\
(0.015)\end{array}$ & $\begin{array}{l}-0.146^{* *} \\
(0.058)\end{array}$ & $\begin{array}{l}-0.149 * * * \\
(0.058)\end{array}$ & $\begin{array}{l}-0.094 \\
(0.073)\end{array}$ \\
\hline $\begin{array}{l}\text { Log of } \\
\text { Assets }\end{array}$ & & $\begin{array}{l}-0.122 * * * \\
(0.012)\end{array}$ & $\begin{array}{l}-0.112 * * * \\
(0.012)\end{array}$ & $\begin{array}{l}-0.117 * * * \\
(0.014)\end{array}$ & $\begin{array}{l}-0.023^{* * *} \\
(0.003)\end{array}$ & $\begin{array}{l}-0.022 * * * \\
(0.003)\end{array}$ & $\begin{array}{l}-0.024 * * * \\
(0.003)\end{array}$ & $\begin{array}{l}-0.016^{*} \\
(0.009)\end{array}$ & $\begin{array}{l}-0.012 \\
(0.009)\end{array}$ & $\begin{array}{l}-0.014 \\
(0.010)\end{array}$ \\
\hline Sales & & $0.048^{* *}$ & 0.011 & 0.000 & $0.020 * * *$ & $0.020 * * *$ & $0.022 * * *$ & $0.080^{* * *}$ & $0.080 * * *$ & $0.058 * *$ \\
\hline Growth & & $(0.024)$ & $(0.024)$ & $(0.027)$ & $(0.005)$ & $(0.005)$ & $(0.006)$ & $(0.022)$ & $(0.022)$ & $(0.024)$ \\
\hline ROA & & $\begin{array}{l}-0.522 * * * \\
(0.111)\end{array}$ & $\begin{array}{l}-0.517^{* * * *} \\
(0.116)\end{array}$ & $\begin{array}{l}-0.638^{* * * *} \\
(0.120)\end{array}$ & $\begin{array}{l}-0.251^{* * *} \\
(0.056)\end{array}$ & $\begin{array}{l}-0.245^{* * * *} \\
(0.056)\end{array}$ & $\begin{array}{l}-0.201 * * * \\
(0.068)\end{array}$ & $\begin{array}{l}0.461 * * * \\
(0.058)\end{array}$ & $\begin{array}{l}0.455^{* * * *} \\
(0.058)\end{array}$ & $\begin{array}{l}0.419 * * * \\
(0.059)\end{array}$ \\
\hline Leverage & & $\begin{array}{l}0.201 * * \\
(0.088)\end{array}$ & $\begin{array}{l}0.260 * * * \\
(0.089)\end{array}$ & $\begin{array}{l}0.389 * * * \\
(0.100)\end{array}$ & $\begin{array}{l}0.040 * * \\
(0.018)\end{array}$ & $\begin{array}{l}0.040 * * \\
(0.018)\end{array}$ & $\begin{array}{l}0.054 * * * \\
(0.020)\end{array}$ & $\begin{array}{l}-0.031 \\
(0.066)\end{array}$ & $\begin{array}{l}-0.031 \\
(0.066)\end{array}$ & $\begin{array}{l}-0.084 \\
(0.069)\end{array}$ \\
\hline Constant & & $\begin{array}{l}2.836^{* * * *} \\
(0.429)\end{array}$ & $\begin{array}{l}2.756^{* * *} \\
(0.439)\end{array}$ & $\begin{array}{l}2.718^{* * * *} \\
(0.489)\end{array}$ & $\begin{array}{l}0.723 * * * \\
(0.213)\end{array}$ & $\begin{array}{l}0.718^{* * * *} \\
(0.215)\end{array}$ & $\begin{array}{l}0.693 * * * \\
(0.205)\end{array}$ & $\begin{array}{l}1.771 \\
(1.263)\end{array}$ & $\begin{array}{l}1.745 \\
(1.259)\end{array}$ & $\begin{array}{l}1.630 \\
(1.297)\end{array}$ \\
\hline $\begin{array}{l}\text { Fixed } \\
\text { Effects }\end{array}$ & & $\begin{array}{l}\text { Country, } \\
\text { Industry, } \\
\text { Year }\end{array}$ & $\begin{array}{l}\text { Country, } \\
\text { Industry, } \\
\text { Year }\end{array}$ & $\begin{array}{l}\text { Country, } \\
\text { Industry, } \\
\text { Year }\end{array}$ & $\begin{array}{l}\text { Country, } \\
\text { Industry, } \\
\text { Year }\end{array}$ & $\begin{array}{l}\text { Country, } \\
\text { Industry, } \\
\text { Year }\end{array}$ & $\begin{array}{l}\text { Country, } \\
\text { Industry, } \\
\text { Year }\end{array}$ & $\begin{array}{l}\text { Country, } \\
\text { Industry, } \\
\text { Year }\end{array}$ & $\begin{array}{l}\text { Country, } \\
\text { Industry, } \\
\text { Year }\end{array}$ & $\begin{array}{l}\text { Country, } \\
\text { Industry, } \\
\text { Year }\end{array}$ \\
\hline $\mathrm{N}$ & & 3,317 & 3,317 & 2,437 & 1,390 & 1,390 & 989 & 3,317 & 3,317 & 2,437 \\
\hline R-squared & & 0.217 & 0.225 & 0.239 & 0.457 & 0.459 & 0.481 & 0.296 & 0.297 & 0.277 \\
\hline
\end{tabular}

Panel A presents results for the regressions of Tobin's q, Cost of Capital and Annual Stock Returns on communication for the sample of firms that cross-listed in 2006-2013. Robust standard errors clustered by firm are presented in parentheses. *, **, and *** denote statistical significance at $10 \%, 5 \%$ and $1 \%$, respectively. P-values are one-tailed when a directional alternative hypothesis is provided and two-tailed otherwise. Variables are described in Appendix I. Continuous variables are winsorized at the 1st and 99th percentile. 


\section{Table 4 - Capital Market Benefits and Investor Communication Around Cross-Listing}

PANEL B: Decline in Valuation Post Cross-Listing and Investor Communication in the Home Country Prior to Cross-Listing

\begin{tabular}{|c|c|c|c|c|c|c|c|}
\hline & & \multicolumn{2}{|c|}{ Tobin's q } & & \multicolumn{2}{|c|}{ " Annual Stock Returns } & \multirow[b]{3}{*}{ Diff. } \\
\hline & & $\begin{array}{c}\text { High Communication } \\
\text { at Home Pre } \\
\text { Cross-Listing }\end{array}$ & $\begin{array}{c}\text { Low Communication } \\
\text { at Home Pre } \\
\text { Cross-Listing } \\
\end{array}$ & & $\begin{array}{c}\text { High Communication } \\
\text { at Home Pre } \\
\text { Cross-Listing }\end{array}$ & $\begin{array}{c}\text { Low Communication } \\
\text { at Home Pre } \\
\text { Cross-Listing } \\
\end{array}$ & \\
\hline & Pred. & $(1)$ & (2) & Diff. & (3) & (4) & \\
\hline Post & - & $\begin{array}{l}\mathbf{- 0 . 3 5 6 * *} \\
(0.166)\end{array}$ & $\begin{array}{c}0.016 \\
(0.080)\end{array}$ & * & $\begin{array}{l}-\mathbf{0 . 3 2 2} * * * \\
(0.116)\end{array}$ & $\begin{array}{l}\mathbf{- 0 . 0 8 6 *} \\
(0.061)\end{array}$ & $* * *$ \\
\hline $\begin{array}{l}\text { Post } \times \text { High Comm. } \\
\text { (in the U.S.) }\end{array}$ & + & $\begin{array}{l}\text { 0.373** } \\
(0.186)\end{array}$ & $\begin{array}{l}\text { 0.184* } \\
(0.143)\end{array}$ & ** & $\begin{array}{l}\text { 0.208* } \\
(0.152)\end{array}$ & $\begin{array}{l}\mathbf{0 . 1 7 6 * *} \\
(0.094)\end{array}$ & * \\
\hline $\begin{array}{l}\text { High Comm. } \\
\text { (in the U.S.) }\end{array}$ & & $\begin{array}{c}0.047 \\
(0.101)\end{array}$ & $\begin{array}{l}-0.060 \\
(0.133)\end{array}$ & & $\begin{array}{l}-0.004 \\
(0.085)\end{array}$ & $\begin{array}{l}-0.190 * * \\
(0.083)\end{array}$ & \\
\hline Controls & & Included & Included & & Included & Included & \\
\hline Fixed Effects & & $\begin{array}{l}\text { Country, } \\
\text { Industry, } \\
\text { Year }\end{array}$ & $\begin{array}{l}\text { Country, } \\
\text { Industry, } \\
\text { Year }\end{array}$ & & $\begin{array}{l}\text { Country, } \\
\text { Industry, } \\
\text { Year }\end{array}$ & $\begin{array}{l}\text { Country, } \\
\text { Industry, } \\
\text { Year }\end{array}$ & \\
\hline $\mathrm{N}$ & & 617 & 2,700 & & 617 & 2,700 & \\
\hline R-squared & & 0.377 & 0.253 & & 0.243 & 0.331 & \\
\hline
\end{tabular}

Panel B presents results for the regressions of Tobin's q and Annual Stock Returns on communication for the sample of firms that cross-listed in 2006-2013. High Communication at Home Pre Cross-Listing is equal to one when the average number of corporate access events in the home country prior to cross-listing is greater than the sample median. Robust standard errors clustered by firm are presented in parentheses. *, **, and *** denote statistical significance at $10 \%, 5 \%$ and $1 \%$, respectively. $\mathrm{P}$-values are one-tailed when a directional alternative hypothesis is provided and two-tailed otherwise. Variables are described in Appendix I. Continuous variables are winsorized at the 1 st and 99 th percentile. 
Table 5 - Capital Market Benefits and Communication Choices of Cross-listed Firms in the Long Run

PANEL A: Valuation, Liquidity and Communication Choices After Cross-Listing

\begin{tabular}{|c|c|c|c|c|c|}
\hline & & Tobin's q & Cost of Capital & Turnover & Bid-Ask Spread \\
\hline & Predictions & $(1)$ & (2) & (3) & (4) \\
\hline Investor Communication Score &,,,+-+- & $\begin{array}{l}\text { 0.116**** } \\
(0.037)\end{array}$ & $\begin{array}{l}-\mathbf{0 . 0 1 1 * * * *} \\
(0.004)\end{array}$ & $\begin{array}{l}\mathbf{0 . 2 6 9 * * *} \\
(0.080)\end{array}$ & $\begin{array}{l}-\mathbf{- 0 . 0 0 3 * *} \\
(0.001)\end{array}$ \\
\hline Equity Issuance & & $\begin{array}{l}0.166^{* * *} \\
(0.046)\end{array}$ & $\begin{array}{c}-0.014 * \\
(0.007)\end{array}$ & $\begin{array}{l}0.250^{* * * *} \\
(0.091)\end{array}$ & $\begin{array}{l}-0.007 * * \\
(0.003)\end{array}$ \\
\hline International Sales & & $\begin{array}{l}0.191 * * \\
(0.075)\end{array}$ & $\begin{array}{l}0.029 * * \\
(0.013)\end{array}$ & $\begin{array}{c}0.217 \\
(0.201)\end{array}$ & $\begin{array}{c}0.001 \\
(0.003)\end{array}$ \\
\hline IFRS & & $\begin{array}{c}0.009 \\
(0.063)\end{array}$ & $\begin{array}{c}-0.011 \\
(0.014)\end{array}$ & $\begin{array}{l}-0.465^{* * *} \\
(0.119)\end{array}$ & $\begin{array}{l}-0.007 * * \\
(0.003)\end{array}$ \\
\hline Log of Assets & & $\begin{array}{l}-0.100^{* * *} \\
(0.017)\end{array}$ & $\begin{array}{l}-0.022 * * * \\
(0.004)\end{array}$ & $\begin{array}{c}0.000 \\
(0.033)\end{array}$ & $\begin{array}{l}-0.006 * * * \\
(0.001)\end{array}$ \\
\hline Sales Growth & & $\begin{array}{c}0.018 \\
(0.030)\end{array}$ & $\begin{array}{c}0.011^{*} \\
(0.006)\end{array}$ & $\begin{array}{l}0.151^{* * *} \\
(0.049)\end{array}$ & $\begin{array}{l}-0.001 \\
(0.002)\end{array}$ \\
\hline ROA & & $\begin{array}{l}-0.129 \\
(0.141)\end{array}$ & $\begin{array}{l}-0.204 * * * \\
(0.053)\end{array}$ & $\begin{array}{c}0.280^{*} \\
(0.149)\end{array}$ & $\begin{array}{l}-0.008 \\
(0.007)\end{array}$ \\
\hline Leverage & & $\begin{array}{l}0.527 * * * \\
(0.110)\end{array}$ & $\begin{array}{l}0.057 * * \\
(0.025)\end{array}$ & $\begin{array}{l}0.626^{* * * *} \\
(0.209)\end{array}$ & $\begin{array}{c}0.002 \\
(0.006)\end{array}$ \\
\hline Constant & & $\begin{array}{l}2.691 * * * \\
(0.317)\end{array}$ & $\begin{array}{l}0.736^{* * * *} \\
(0.222)\end{array}$ & $\begin{array}{c}0.261 \\
(0.600)\end{array}$ & $\begin{array}{l}0.071^{* * *} \\
(0.025)\end{array}$ \\
\hline Fixed Effects & & $\begin{array}{c}\text { Country, } \\
\text { Industry, } \\
\text { Year }\end{array}$ & $\begin{array}{c}\text { Country, } \\
\text { Industry, } \\
\text { Year }\end{array}$ & $\begin{array}{c}\text { Country, } \\
\text { Industry, } \\
\text { Year }\end{array}$ & $\begin{array}{c}\text { Country, } \\
\text { Industry, } \\
\text { Year }\end{array}$ \\
\hline $\mathrm{N}$ & & 3,347 & 1,430 & 1,806 & 837 \\
\hline R-squared & & 0.198 & 0.412 & 0.353 & 0.357 \\
\hline
\end{tabular}

Panel A presents results for Tobin's q, Cost of Capital, Turnover in the U.S. and Bid-Ask Spread in the U.S. on investor communication after crosslisting for all cross-listings. Robust standard errors clustered by firm are presented in parentheses. *,**, and *** denote statistical significance at $10 \%$, $5 \%$ and $1 \%$, respectively. P-values are one-tailed when a directional alternative hypothesis is provided and two-tailed otherwise. Variables are described in Appendix I. Continuous variables are winsorized at the 1 st and 99 th percentiles. 


\section{Table 5 - Capital Market Benefits and Communication Choices of Cross-listed Firms in the Long Run}

PANEL B: Path Analysis

\begin{tabular}{|c|c|c|c|}
\hline \multirow[t]{2}{*}{ Path } & \multicolumn{2}{|c|}{ Regression Coefficients } & \multirow{2}{*}{$\begin{array}{c}\text { Total Path } \\
(3)\end{array}$} \\
\hline & $(1)$ & $(2)$ & \\
\hline Indirect: Inv. Comm. $\rightarrow$ Log Number Analysts $\rightarrow$ Tobin's q & $0.2580 * * *$ & $0.0850 * *$ & $0.0219 * * *$ \\
\hline Indirect: Inv. Comm. $\rightarrow$ Log Number Institutional Investors $\rightarrow$ Tobin's q & $0.2071 * * *$ & $0.0463 * *$ & $0.0096 * *$ \\
\hline Indirect: Inv. Comm. $\rightarrow$ Log Number Media Articles $\rightarrow$ Tobin's q & $0.3074 * * *$ & 0.0222 & $0.0068^{*}$ \\
\hline Direct: Inv. Comm. $\rightarrow$ Tobin's q & & $0.0776^{* *}$ & $0.0776^{* *}$ \\
\hline Total & & & $0.116 * * *$ \\
\hline Indirect: Inv. Comm. $\rightarrow$ Log Number Analysts $\rightarrow$ Cost of Capital & $0.2580 * * *$ & $-0.0305 * * *$ & $-0.0079 * * *$ \\
\hline Indirect: Inv. Comm. $\rightarrow$ Log Number Institutional Investors $\rightarrow$ Cost of Capital & $0.2071 * * *$ & 0.0032 & 0.0007 \\
\hline Indirect: Inv. Comm. $\rightarrow$ Log Number Media Articles $\rightarrow$ Cost of Capital & $0.3074 * * *$ & 0.0006 & 0.0002 \\
\hline Direct: Inv. Comm. $\rightarrow$ Cost of Capital & & $-0.0089 * *$ & $-0.0089 * *$ \\
\hline Total & & & $-0.011 * * *$ \\
\hline Indirect: Inv. Comm. $\rightarrow$ Log Number Analysts $\rightarrow$ Turnover & $0.2580 * * *$ & $0.2096^{* * *}$ & $0.0541 * * *$ \\
\hline Indirect: Inv. Comm. $\rightarrow$ Log Number Institutional Investors $\rightarrow$ Turnover & $0.2071 * * *$ & $0.0837 * *$ & $0.0173^{* *}$ \\
\hline Indirect: Inv. Comm. $\rightarrow$ Log Number Media Articles $\rightarrow$ Turnover & $0.3074 * * *$ & $0.0689 *$ & $0.0212 * *$ \\
\hline Direct: Inv. Comm. $\rightarrow$ Turnover & & $0.1802 * *$ & $0.1802 * *$ \\
\hline Total & & & $0.269 * * *$ \\
\hline Indirect: Inv. Comm. $\rightarrow$ Log Number Analysts $\rightarrow$ Bid-Ask Spread & $0.2580 * * *$ & $-0.0048 * * *$ & $-0.0012 * * *$ \\
\hline Indirect: Inv. Comm. $\rightarrow$ Log Number Institutional Investors $\rightarrow$ Bid-Ask Spread & $0.2071 * * *$ & -0.0002 & -0.0000 \\
\hline Indirect: Inv. Comm. $\rightarrow$ Log Number Media Articles $\rightarrow$ Bid-Ask Spread & $0.3074 * * *$ & $-0.0008^{*}$ & -0.0002 \\
\hline Direct: Inv. Comm. $\rightarrow$ Bid-Ask Spread & & -0.0012 & -0.0012 \\
\hline Total & & & $-0.003 * *$ \\
\hline
\end{tabular}

Panel B presents a path analysis to show the magnitude of the direct and indirect effects of Investor Communication on each outcome variable. Colum 1 presents the coefficients of multivariate regressions of investor communication on the following variables. Column 2 presents the coefficients of multivariate regressions of following and investor communication on the outcome variables. The indirect path between the Investor Communication and each outcome variable through the following variables is obtained by multiplying the coefficients on columns 1 and 2. I use the Preacher and Hayes (2008) method to compute bootstrap standard errors for the indirect paths. The direct path between IR and each outcome variable is the coefficient of Investor Communication Score on the outcome variables controlling for the following variables. The total effect is the sum of the indirect and direct paths. Variables are described in Appendix I. 
Table 5 - Capital Market Benefits and Communication Choices of Cross-listed Firms in the Long Run

\section{PANEL C: Communication Choices and Likelihood of Delisting}

Delisting from the U.S.

\begin{tabular}{|c|c|c|}
\hline & Prediction & $(1)$ \\
\hline Investor Communication Score & - & $\begin{array}{l}-\mathbf{- 0 . 2 9 3 * *} \\
(0.144)\end{array}$ \\
\hline Equity Issuance & & $\begin{array}{l}-0.638^{*} \\
(0.335)\end{array}$ \\
\hline International Sales Ratio & & $\begin{array}{l}-0.335 \\
(0.337)\end{array}$ \\
\hline IFRS & & $\begin{array}{c}0.169 \\
(0.196)\end{array}$ \\
\hline Log of Assets & & $\begin{array}{l}-0.129^{*} \\
(0.076)\end{array}$ \\
\hline Sales Growth & & $\begin{array}{c}-0.175^{* *} \\
(0.070)\end{array}$ \\
\hline ROA & & $\begin{array}{l}0.586^{*} \\
(0.301)\end{array}$ \\
\hline Leverage & & $\begin{array}{c}0.303 \\
(0.371)\end{array}$ \\
\hline Constant & & $\begin{array}{c}-11.451^{* * * *} \\
(1.943)\end{array}$ \\
\hline Fixed Effects & & $\begin{array}{l}\text { Country, } \\
\text { Industry, } \\
\text { Year }\end{array}$ \\
\hline $\mathrm{N}$ & & 3,347 \\
\hline Pseudo R-squared & & 0.152 \\
\hline
\end{tabular}




\section{Table 6 - Cross-Sectional Tests}

\section{PANEL A: Country Characteristics}

\begin{tabular}{|c|c|c|c|c|c|c|c|c|c|c|c|c|c|}
\hline & \multirow[b]{4}{*}{ Pred. } & \multicolumn{12}{|c|}{ Tobin's Q } \\
\hline & & $(1)$ & $(2)$ & \multirow{2}{*}{\multicolumn{4}{|c|}{$\begin{array}{c}(3) \quad(4) \\
\text { Language }\end{array}$}} & $(5)$ & $(6)$ & & $(7)$ & $(8)$ & \\
\hline & & \multicolumn{2}{|c|}{ Cultural Distance } & & & & & \multicolumn{2}{|c|}{ Corruption } & \multicolumn{4}{|c|}{ Legal Tradition } \\
\hline & & Low & High & Diff. & English & Non-English & Diff. & Low & High & Diff. & Common Law & Code Law & Diff. \\
\hline Inv. Comm. Score & + & $\begin{array}{l}\mathbf{0 . 1 2 3} * * * \\
(0.043)\end{array}$ & $\begin{array}{c}\text { 0.075* } \\
(0.058)\end{array}$ & $*$ & $\begin{array}{l}\mathbf{0 . 0 9 1 * *} \\
(0.051)\end{array}$ & $\begin{array}{l}\mathbf{0 . 1 2 9} * * * \\
(0.048)\end{array}$ & Not Sig. & $\begin{array}{l}\mathbf{0 . 1 2 2} * * * \\
(0.043)\end{array}$ & $\begin{array}{l}\mathbf{0 . 0 7 9} * \\
(0.057)\end{array}$ & $*$ & $\begin{array}{l}\mathbf{0 . 0 9 6 * *} \\
(0.045)\end{array}$ & $\begin{array}{l}\text { 0.105** } \\
(0.054)\end{array}$ & Not Sig. \\
\hline Controls & & Included & Included & & Included & Included & & Included & Included & & Included & Included & \\
\hline Fixed Effects & & $\begin{array}{c}\text { Country, } \\
\text { Industry, } \\
\text { Year }\end{array}$ & $\begin{array}{c}\text { Country, } \\
\text { Industry, } \\
\text { Year }\end{array}$ & & $\begin{array}{c}\text { Country, } \\
\text { Industry, } \\
\text { Year }\end{array}$ & $\begin{array}{c}\text { Country, } \\
\text { Industry, } \\
\text { Year }\end{array}$ & & $\begin{array}{c}\text { Country, } \\
\text { Industry, } \\
\text { Year }\end{array}$ & $\begin{array}{c}\text { Country, } \\
\text { Industry, } \\
\text { Year }\end{array}$ & & $\begin{array}{c}\text { Country, } \\
\text { Industry, } \\
\text { Year }\end{array}$ & $\begin{array}{l}\text { Country, } \\
\text { Industry, } \\
\text { Year }\end{array}$ & \\
\hline $\mathrm{N}$ & & 1,510 & 1,837 & & 1,222 & 2,125 & & 1,685 & 1,662 & & 1,508 & 1,562 & \\
\hline R-squared & & 0.232 & 0.177 & & 0.209 & 0.210 & & 0.253 & 0.178 & & 0.205 & 0.207 & \\
\hline
\end{tabular}

PANEL B: Firm Characteristics

\begin{tabular}{|c|c|c|c|c|c|c|c|}
\hline & \multirow[b]{4}{*}{ Pred. } & \multicolumn{6}{|c|}{ Tobin's Q } \\
\hline & & $(1)$ & $(2)$ & \multirow[b]{3}{*}{ Diff. } & (3) & (4) & \multirow[b]{3}{*}{ Diff. } \\
\hline & & \multicolumn{2}{|c|}{ Level of Listing } & & \multicolumn{2}{|c|}{ News Content } & \\
\hline & & Exchange & OTC & & Good News & Bad News & \\
\hline Inv. Comm. Score & + & $\begin{array}{l}\mathbf{0 . 1 4 5 * * *} \\
(0.047)\end{array}$ & $\begin{array}{c}\mathbf{0 . 0 7 5} * \\
(0.052)\end{array}$ & * & $\begin{array}{l}\mathbf{0 . 1 2 4 * * *} \\
(0.046)\end{array}$ & $\begin{array}{l}\mathbf{0 . 0 9 7 * *} \\
(0.045)\end{array}$ & Not Sig. \\
\hline $\begin{array}{l}\text { Controls } \\
\text { Fixed Effects }\end{array}$ & & $\begin{array}{l}\text { Included } \\
\text { Country, } \\
\text { Industry, Year }\end{array}$ & $\begin{array}{l}\text { Included } \\
\text { Country, } \\
\text { Industry, Year }\end{array}$ & & $\begin{array}{c}\text { Included } \\
\text { Country, } \\
\text { Industry, Year }\end{array}$ & $\begin{array}{c}\text { Included } \\
\text { Country, Industry, } \\
\text { Year }\end{array}$ & \\
\hline $\mathrm{N}$ & & 910 & 2,437 & & 742 & 1,037 & \\
\hline R-squared & & 0.366 & 0.206 & & 0.296 & 0.229 & \\
\hline
\end{tabular}

Table 6 presents results for Tobin's q on investor communication after cross-listing for all cross-listings partitioned by high and low Cultural Distance, English and non-English countries, high and low Corruption, Common Law and Code Law countries, OTC and Exchange cross-listings, and Good and Bad News firm-years. High cultural distance equals one when the Cultural Distance score is greater than the median. High corruption equals one when the Control of Corruption score is lesser than the median. Level I listings and 144a private placements are classified as OTC, Levels II and III are classified as Exchange listings. News content is measured by the yearly average sentiment (CSS) of firm-initiated press releases according to RavenPack. Robust standard errors clustered by firm are presented in parentheses. *, **, and *** denote statistical significance at $10 \%, 5 \%$ and $1 \%$, respectively. P-values are one-tailed when a directional alternative hypothesis is provided and two-tailed otherwise. Variables are described in Appendix I. Continuous variables are winsorized at the 1 st and 99 th percentiles. 
Table 7 - Instrumental Variables Regressions

PANEL A: Two-Stage Least Squares Regressions

\begin{tabular}{|c|c|c|c|c|c|c|c|c|c|c|c|}
\hline & & $\begin{array}{c}\text { Inv. Comm. } \\
\text { Score }\end{array}$ & Tobin's q & $\begin{array}{l}\text { Cost of } \\
\text { Capital }\end{array}$ & Turnover & $\begin{array}{l}\text { Bid-Ask } \\
\text { Spread }\end{array}$ & $\begin{array}{c}\text { Corporate } \\
\text { Access } \\
\text { U.S. } \\
\end{array}$ & Tobin's q & $\begin{array}{l}\text { Cost of } \\
\text { Capital }\end{array}$ & Turnover & $\begin{array}{l}\text { Bid-Ask } \\
\text { Spread }\end{array}$ \\
\hline & Pred. & $(1)$ & $(2)$ & (3) & $(4)$ & $(5)$ & $(6)$ & (7) & $(8)$ & $(9)$ & $(10)$ \\
\hline Inv. Comm. Score &,,,+-+- & & $\begin{array}{l}\text { 0.313** } \\
(0.134)\end{array}$ & $\begin{array}{l}-\mathbf{- 0 . 0 2 5 * *} \\
(0.014)\end{array}$ & $\begin{array}{l}\mathbf{0 . 8 3 0} * * * \\
(0.254)\end{array}$ & $\begin{array}{l}-\mathbf{- 0 . 0 1 1 * *} \\
(0.007)\end{array}$ & & & & & \\
\hline Corporate Access U.S. &,,,+-+- & & & & & & & $\begin{array}{l}\mathbf{0 . 4 3 0} * * \\
(0.203)\end{array}$ & $\begin{array}{l}\mathbf{- 0 . 0 5 4} * \\
(0.036)\end{array}$ & $\begin{array}{l}1.149 * * * \\
(0.453)\end{array}$ & $\begin{array}{c}-\mathbf{0 . 0 1 1} * \\
(0.008)\end{array}$ \\
\hline Direct Flight & + & $\begin{array}{l}\mathbf{0 . 3 2 5} * * * \\
(0.038)\end{array}$ & & & & & $\begin{array}{l}\mathbf{0 . 2 3 7 * * *} \\
(0.057)\end{array}$ & & & & \\
\hline Imports and Exports & & -0.064 & -0.063 & -0.003 & 0.078 & $0.026^{*}$ & -0.326 & 0.057 & -0.011 & 0.270 & 0.018 \\
\hline FDI & & 0.009 & -0.028 & -0.003 & 0.056 & 0.002 & -0.052 & -0.003 & -0.005 & 0.113 & 0.001 \\
\hline Corporate Access Home & & $0.239 * * *$ & 0.004 & 0.004 & $-0.170 * *$ & $0.003 *$ & $0.641 * * *$ & -0.197 & 0.034 & $-0.692 * *$ & 0.008 \\
\hline Equity Issuance & & $0.226 * * *$ & $0.240 *$ & 0.026 & $0.317 *$ & $-0.011 * * *$ & $0.486 * * *$ & 0.101 & 0.022 & 0.101 & -0.003 \\
\hline Exchange Cross-Listing & & $0.528 * * *$ & -0.028 & 0.022 & $-0.466^{* * *}$ & $0.004^{*}$ & $0.487 * * *$ & -0.072 & 0.037 & $-0.657 * * *$ & 0.005 \\
\hline IFRS & & 0.081 & -0.010 & -0.011 & -0.069 & -0.006 & $0.266^{* * *}$ & -0.099 & 0.004 & -0.245 & 0.001 \\
\hline International Sales & & $0.230 * * *$ & $0.142 * *$ & $0.025 * *$ & -0.054 & 0.005 & $0.389 * * *$ & 0.047 & $0.031 * *$ & -0.260 & 0.010 \\
\hline Log of Assets & & $0.129 * * *$ & $-0.126^{* * *}$ & $-0.022 * * *$ & -0.045 & $-0.006^{* * *}$ & $0.055 * * *$ & $-0.109 * * *$ & $-0.023 * * *$ & 0.002 & $-0.007 * * *$ \\
\hline Sales Growth & & 0.003 & 0.019 & 0.009 & 0.039 & -0.000 & $0.057 *$ & -0.004 & 0.010 & -0.020 & 0.002 \\
\hline ROA & & -0.068 & -0.087 & $-0.208 * * *$ & -0.014 & -0.007 & -0.036 & -0.093 & $-0.202 * * *$ & -0.059 & -0.006 \\
\hline Leverage & & $-0.223 * * *$ & $0.567 * * *$ & $0.065 * * *$ & $0.195^{*}$ & 0.001 & $-0.553 * * *$ & $0.735 * * *$ & 0.040 & $0.711 * *$ & -0.004 \\
\hline Constant & & -1.135 & 4.998 & 0.880 & -1.372 & $-0.580 *$ & 8.269 & 1.293 & 1.108 & -8.056 & -0.364 \\
\hline Fixed Effects & & $\begin{array}{c}\text { Country, } \\
\text { Industry, } \\
\text { Year }\end{array}$ & $\begin{array}{c}\text { Country, } \\
\text { Industry, } \\
\text { Year }\end{array}$ & $\begin{array}{c}\text { Country, } \\
\text { Industry, } \\
\text { Year }\end{array}$ & $\begin{array}{c}\text { Country, } \\
\text { Industry, } \\
\text { Year }\end{array}$ & $\begin{array}{c}\text { Country, } \\
\text { Industry, } \\
\text { Year }\end{array}$ & $\begin{array}{c}\text { Country, } \\
\text { Industry, } \\
\text { Year }\end{array}$ & $\begin{array}{c}\text { Country, } \\
\text { Industry, } \\
\text { Year }\end{array}$ & $\begin{array}{c}\text { Country, } \\
\text { Industry, } \\
\text { Year }\end{array}$ & $\begin{array}{c}\text { Country, } \\
\text { Industry, } \\
\text { Year }\end{array}$ & $\begin{array}{c}\text { Country, } \\
\text { Industry, } \\
\text { Year }\end{array}$ \\
\hline Adj. R-squared & & 0.533 & & & & & 0.333 & & & & \\
\hline Robust F & & 73.768 & & & & & 17.188 & & & & \\
\hline $\begin{array}{l}\text { Minimum eigenvalue } \\
\text { statistic }\end{array}$ & & 68.990 & & & & & 10.561 & & & & \\
\hline $\begin{array}{l}\text { 2SLS Size of nominal } 5 \% \\
\text { Wald test }\end{array}$ & & 5.530 & & & & & 5.530 & & & & \\
\hline
\end{tabular}

Panel A presents coefficients from the two-stage least squares regressions. Column 1 and 6 present first-stage regression results for the investor communication score and corporate access events in the U.S. Robust standard errors clustered by firm are presented in parentheses. *, **, and *** denote statistical significance at $10 \%, 5 \%$ and $1 \%$, respectively. P-values are onetailed when a directional alternative hypothesis is provided and two-tailed otherwise. Variables are described in Appendix I. Continuous variables are winsorized at the 1st and 99th percentiles. 


\section{Table 7 - Instrumental Variables Regressions}

PANEL B: Average Change in Communication for Direct Flight Initiations and Terminations

\begin{tabular}{lcccc} 
& Firms & Pre & Post & Diff. \\
\hline Direct Flight Initiation: & & & 0.822 & $0.318^{* * *}$ \\
Mean Investor Communication Score & 53 & 0.504 & 0.333 & $0.197^{* *}$ \\
Mean Corporate Access U.S. & 53 & 0.136 & & 0.599 \\
Direct Flight Termination: & & & $-0.263^{* *}$ \\
Mean Investor Communication Score & 29 & 0.862 & 0.167 & $-0.283^{* *}$ \\
Mean Corporate Access U.S. & 29 & 0.450 & & \\
\hline
\end{tabular}

Panel B presents the mean investor communication scores and number of corporate access events held in the U.S. before and after a change in flight availability for cross-listed firms that experienced a direct flight initiation or termination during the sample period. 
Table 8 - Communication with Local versus U.S. investors

PANEL A: Corporate Access Events Held in the U.S. and in the Home Country

\begin{tabular}{|c|c|c|c|c|c|}
\hline & & Tobin's q & Cost of Capital & Turnover U.S. & Bid-Ask Spread U.S. \\
\hline & Predictions & (1) & $(2)$ & (3) & (4) \\
\hline $\begin{array}{l}\text { Proportion Corp. Access } \\
\text { Home vs U.S. }\end{array}$ &,,,-+-+ & $\begin{array}{l}-\mathbf{- 0 . 2 0 5 * *} \\
(0.101)\end{array}$ & $\begin{array}{c}\mathbf{0 . 0 2 5} * * \\
(0.013)\end{array}$ & $\begin{array}{l}-0.084 \\
(0.151)\end{array}$ & $\begin{array}{c}0.001 \\
(0.003)\end{array}$ \\
\hline Controls & & Included & Included & Included & Included \\
\hline Fixed Effects & & $\begin{array}{c}\text { Country, } \\
\text { Industry, } \\
\text { Year }\end{array}$ & $\begin{array}{c}\text { Country, } \\
\text { Industry, } \\
\text { Year }\end{array}$ & $\begin{array}{c}\text { Country, } \\
\text { Industry, } \\
\text { Year }\end{array}$ & $\begin{array}{c}\text { Country, } \\
\text { Industry, } \\
\text { Year }\end{array}$ \\
\hline $\mathrm{N}$ & & 1,004 & 465 & 641 & 349 \\
\hline R-squared & & 0.226 & 0.429 & 0.401 & 0.490 \\
\hline
\end{tabular}

PANEL B: Falsification Tests

\begin{tabular}{|c|c|c|c|c|c|c|}
\hline & \multicolumn{3}{|c|}{ Turnover } & \multicolumn{3}{|c|}{ Bid-Ask Spread } \\
\hline & \multirow{2}{*}{$\begin{array}{c}\text { U.S. } \\
(1) \\
\end{array}$} & \multicolumn{2}{|c|}{ Home } & \multirow{2}{*}{$\begin{array}{l}\text { U.S. } \\
(4) \\
\end{array}$} & \multicolumn{2}{|c|}{ Home } \\
\hline & & $(2)$ & (3) & & $(5)$ & (6) \\
\hline $\begin{array}{l}\text { Corporate Access } \\
\text { Home }\end{array}$ & $\begin{array}{l}-0.034 \\
(0.038)\end{array}$ & & & $\begin{array}{c}0.001 \\
(0.001)\end{array}$ & & \\
\hline $\begin{array}{l}\text { Corporate Access } \\
\text { U.S. }\end{array}$ & & $\begin{array}{l}-0.020 \\
(0.015)\end{array}$ & & & $\begin{array}{l}-0.000 \\
(0.001)\end{array}$ & \\
\hline $\begin{array}{l}\text { Inv. Comm. Score } \\
\text { (U.S.) }\end{array}$ & & & $\begin{array}{l}-0.007 \\
(0.047)\end{array}$ & & & $\begin{array}{l}-0.001 \\
(0.002)\end{array}$ \\
\hline $\begin{array}{l}\text { Controls } \\
\text { Fixed Effects }\end{array}$ & $\begin{array}{c}\text { Included } \\
\text { Country, } \\
\text { Industry, } \\
\text { Year }\end{array}$ & $\begin{array}{c}\text { Included } \\
\text { Country, } \\
\text { Industry, } \\
\text { Year }\end{array}$ & $\begin{array}{c}\text { Included } \\
\text { Country, } \\
\text { Industry, } \\
\text { Year }\end{array}$ & $\begin{array}{c}\text { Included } \\
\text { Country, } \\
\text { Industry, } \\
\text { Year }\end{array}$ & $\begin{array}{c}\text { Included } \\
\text { Country, } \\
\text { Industry, } \\
\text { Year }\end{array}$ & $\begin{array}{c}\text { Included } \\
\text { Country, } \\
\text { Industry, } \\
\text { Year }\end{array}$ \\
\hline $\mathrm{N}$ & 1,806 & 1,295 & 1,295 & 837 & 2,766 & 2,766 \\
\hline R-squared & 0.338 & 0.308 & 0.307 & 0.350 & 0.321 & 0.321 \\
\hline
\end{tabular}

Panel A presents the results for regressions of the proportion of corporate access events held in the firm's home country versus in the U.S. during the year on valuation and liquidity in the U.S. variables. Robust standard errors clustered by firm are presented in parentheses. $*, * *$, and $* * *$ denote statistical significance at $10 \%, 5 \%$ and $1 \%$, respectively. P-values are one-tailed when a directional alternative hypothesis is provided and two-tailed otherwise. Variables are described in Appendix I. Continuous variables are winsorized at the 1st and 99th percentiles. Panel B presents regressions of corporate access events held in the firms' home country on liquidity variables in the U.S. and corporate access and investor communication scores in the U.S. on liquidity variables in the home country's exchange. Robust standard errors clustered by firm are presented in parentheses. *, **, and *** denote statistical significance at $10 \%, 5 \%$ and $1 \%$, respectively. P-values are one-tailed when a directional alternative hypothesis is provided and two-tailed otherwise. Variables are described in Appendix I. Continuous variables are winsorized at the 1st and 99th percentiles. 
Table 9 - Initiation and Termination of Investor Communication Activities and Capital Market Benefits

\begin{tabular}{|c|c|c|c|c|c|c|c|c|c|c|c|c|c|}
\hline & \multirow[b]{2}{*}{ Firms } & \multicolumn{3}{|c|}{ Mean Tobin's q } & \multicolumn{3}{|c|}{ Mean Cost of Capital } & \multicolumn{3}{|c|}{ Mean Turnover } & \multicolumn{3}{|c|}{ Mean Bid-Ask Spread } \\
\hline & & Pre & Post & Diff. & Pre & Post & Diff. & Pre & Post & Diff. & Pre & Post & Diff. \\
\hline \multicolumn{14}{|l|}{ Initiation of: } \\
\hline Corporate Access US & 258 & 1.702 & 1.857 & $0.155^{* *}$ & 0.197 & 0.168 & $-0.029 * *$ & 0.761 & 0.655 & -0.106 & 0.017 & 0.013 & $-0.004 *$ \\
\hline Conference Calls & 296 & 1.630 & 1.547 & -0.083 & 0.213 & 0.180 & $-0.033 * * *$ & 0.211 & 0.880 & $0.669^{* * *}$ & 0.010 & 0.013 & 0.003 \\
\hline Press Releases & 187 & 1.579 & 1.699 & $0.119^{*}$ & 0.226 & 0.182 & $-0.045^{* * *}$ & 0.088 & 0.309 & $0.220 * * *$ & 0.027 & 0.013 & $-0.013^{* *}$ \\
\hline Management Forecasts & 229 & 1.698 & 1.588 & $-0.110 * *$ & 0.160 & 0.165 & 0.005 & 0.364 & 1.310 & $0.946^{* * *}$ & 0.013 & 0.012 & -0.001 \\
\hline \multicolumn{14}{|l|}{ Termination of: } \\
\hline Corporate Access US & 225 & 1.702 & 1.559 & $-0.143 * *$ & 0.188 & 0.193 & 0.005 & 0.889 & 0.744 & -0.145 & 0.013 & 0.019 & $0.006^{*}$ \\
\hline Conference Calls & 146 & 1.591 & 1.662 & 0.071 & 0.167 & 0.219 & $0.051^{* * *}$ & 0.345 & 0.130 & $-\overline{0} 214 * * *$ & 0.013 & 0.024 & $0.011^{*}$ \\
\hline Press Releases & 312 & 1.638 & 1.501 & $-0.137 * *$ & 0.177 & 0.218 & $0.040 * * *$ & 0.393 & 0.354 & -0.039 & 0.012 & 0.020 & $0.008 * *$ \\
\hline Management Forecasts & 149 & 1.468 & 1.671 & $0.202 * * *$ & 0.156 & 0.175 & $0.019^{*}$ & 0.917 & 0.249 & - & 0.013 & 0.013 & 0.000 \\
\hline
\end{tabular}

Table 9 presents the mean Tobin's q, Cost of Capital, Turnover in the U.S. and Bid-Ask Spread in the U.S. of cross-listed firms before and after the initiation or termination of each of the investor communication activities. *, $* *$, and $* * *$ denote statistical significance at $10 \%, 5 \%$ and $1 \%$, respectively. 


\section{Table 10 - Valuation Premium of Cross-Listed Firms Relative to Non-Cross-Listed Firms and Communication Choices}

PANEL A: Valuation Premium of Cross-listed versus Matched Non-Cross-Listed Firms and Communication Choices After Crosslisting

\begin{tabular}{|c|c|c|c|c|c|c|c|c|}
\hline & \multirow[b]{2}{*}{ Prediction } & \multicolumn{7}{|c|}{ Tobin's q } \\
\hline & & (1) & (2) & (3) & (4) & (5) & $(6)$ & (7) \\
\hline Xlisted & + & $\begin{array}{l}\mathbf{0 . 1 2 1}^{* * *} \\
(0.052)\end{array}$ & $\begin{array}{c}0.059 \\
(0.052)\end{array}$ & $\begin{array}{c}\text { 0.075* } \\
(0.054)\end{array}$ & $\begin{array}{c}0.059 \\
(0.053)\end{array}$ & $\begin{array}{l}\mathbf{0 . 0 9 7 * *} \\
(0.054)\end{array}$ & $\begin{array}{c}0.020 \\
(0.055)\end{array}$ & $\begin{array}{c}0.023 \\
(0.055)\end{array}$ \\
\hline DCorporate Access US & + & & $\begin{array}{l}\mathbf{0 . 3 3 0 * * * *} \\
(0.064)\end{array}$ & & & & $\begin{array}{l}\mathbf{0 . 2 7 5}^{* *} \\
(0.068)\end{array}$ & \\
\hline DConference Call & + & & & $\begin{array}{l}\mathbf{0 . 1 5 8}^{* * *} \\
(0.049)\end{array}$ & & & $\begin{array}{l}0.031 \\
(0.048)\end{array}$ & \\
\hline DPress Release & + & & & & $\begin{array}{l}\mathbf{0 . 2 0 4} * * * \\
(0.045)\end{array}$ & & $\begin{array}{l}\mathbf{0 . 1 4 7 * *} \\
(0.043)\end{array}$ & \\
\hline DManagement Forecast & + & & & & & $\begin{array}{l}\text { 0.117*** } \\
(0.058)\end{array}$ & $\begin{array}{l}-0.021 \\
(0.063)\end{array}$ & \\
\hline Inv. Comm. Score & + & & & & & & & $\begin{array}{l}\mathbf{0 . 1 3 7 * * *} \\
(0.030)\end{array}$ \\
\hline Controls & & Included & Included & Included & Included & Included & Included & Included \\
\hline $\mathrm{N}$ & & 5,648 & 5,648 & 5,648 & 5,648 & 5,648 & 5,648 & 5,648 \\
\hline R-squared & & 0.060 & 0.072 & 0.064 & 0.068 & 0.062 & 0.076 & 0.072 \\
\hline
\end{tabular}

PANEL B: Valuation Premium of Cross-Listed Firms Relative to Non-Cross-Listed Firms by Indicator Communication Variable

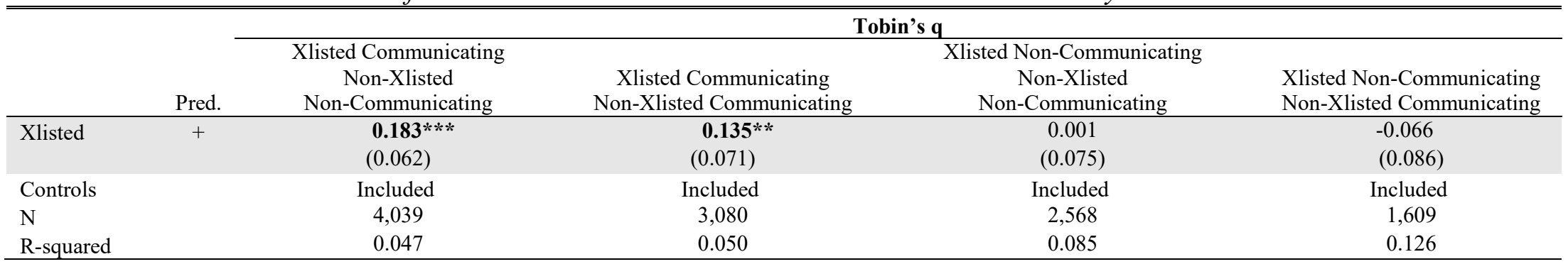

Panel A presents results for the regressions of Tobin's q on communication after cross-listing for all cross-listings and a matched sample of non-cross-listed firm-years. Robust standard errors clustered by firm are presented in parentheses. *,**, and *** denote statistical significance at $10 \%, 5 \%$ and $1 \%$, respectively. P-values are one-tailed when a directional alternative hypothesis is provided and two-tailed otherwise. Variables are described in Appendix I. Continuous variables are winsorized at the 1st and 99th percentiles. Panel B presents results for the regressions of Tobin's q on Xlisted for all cross-listed and non-cross-listed firm-years partitioning firms based on their communication choices. A firm is considered a communicating firm in a given year when at least one of the communication indicator variables is equal to one. Robust standard errors clustered by firm are presented in parentheses. *, **, and *** denote statistical significance at $10 \%, 5 \%$ and $1 \%$, respectively. P-values are one-tailed when a directional alternative hypothesis is provided and two-tailed otherwise. Variables are described in Appendix I. Continuous variables are winsorized at the 1st and 99th percentiles. 
APPENDIX 


\title{
Variable Definitions
}

\author{
Variable \\ Definition \\ Annual Stock Returns \\ Cumulative monthly stock returns during the year. \\ Bid-Ask Spread \\ Annual average of the daily bid-ask spreads in the U.S. Daily bid-ask spreads are computed as the \\ daily ask quote minus the daily bid quote divided by the midpoint between the bid and the ask quotes. \\ Common Law \\ Indicator variable equal to one for countries with an English Common Law legal system according to \\ the CIA Factbook. Countries with mixed Code and Common Law systems are considered Code Law \\ countries. \\ Conference Calls \\ Number of conference calls in English held by the firm during the year according to Bloomberg. \\ Corporate Access US \\ Number of capital market conferences, investor days and non-deal roadshows in the U.S. that the firm \\ participated in during the year according to Bloomberg. \\ Corporate Access Home \\ Number of capital market conferences, investor days and non-deal roadshows in the home country \\ that the firm participated in during the year according to Bloomberg. \\ An aggregated score that ranges from -2.5 to 2.5 and captures perceptions of the extent to which \\ Corruption \\ public power is exercised for private gain, including both petty and grand forms of corruption, as well \\ as "capture" of the state by elites and private interests. This data comes from the Worldwide \\ Governance Indicators (WGI). \\ Cost of Capital \\ Implied cost of capital using the residual income valuation model of Claus and Thomas (2001) and \\ analyst earnings forecasts from $\mathrm{I} / \mathrm{B} / \mathrm{E} / \mathrm{S}$. General assumptions and data requirements follow those in \\ the appendix of Hail and Leuz (2009).
}

Country-Industry Peers

Average number of corporate access events or conference calls held by firms in the same country and Fama-French 12 industry, excluding the firm itself.

Average of the differences in the scores for Hofstede's six cultural dimensions between the U.S. and the firm's country. The six dimensions include the Power Distance Index, Individualism versus

Cultural Distance Collectivism, the Uncertainty Avoidance Index, Masculinity versus Femininity, Long-Term Orientation versus Short-Term Orientation, and Indulgence versus Restraint. This data is from The Hofstede Centre's website.

An indicator variable equal to one if at least one of the communication indicator variables

DCommunication (DCorporate Access US, DConference Call, DPress Release or DManagement Forecast) is equal to one.

DConference Call

An indicator variable equal to one if the firm held at least one conference call in English during the year.

An indicator variable equal to one if the firm participated in at least one corporate access event in the U.S. during the year. 


\section{Variable Definitions (Continued)}

\begin{tabular}{ll}
\hline Variable & Definition \\
\hline
\end{tabular}

Direct Flight

DManagement Forecast

DPress Release

English

Equity Issuance

Exchange Cross-listing

FDI

High Communication

IFRS

Imports and Exports

Index Participant

International Sales

Inv. Comm. Score

Lead Asset Growth

Lead Earnings Growth

Leverage

Log Assets
An indicator variable equal to one if an airport less than 50 miles away from the city of a firm's headquarters has a direct flight to JFK, LGA or EWR according to the T-100 segment database from the U.S. Department of Transportation.

An indicator variable equal to one if the firm disclosed at least one forecast during the year.

An indicator variable equal to one if the firm disseminated at least one press release during the year using PR Newswire or Business Wire.

Indicator variable equal to one for countries where English is an official language (de jure or de facto) according to the CIA Factbook.

Indicator variable equal to one if the firm issued shares during the year according to Datastream.

An indicator variable equal to one if the firm is listed on NYSE or NASDAQ.

Log of the Foreign Direct Investment in the firm home country during the year according to the World Bank.

Indicator variable equal to one for cross-listed firms with investor communication scores in the upper quartile.

Indicator variable equal to one for observations from the IFRS countries, with fiscal year ends after the mandatory adoption date. I follow Christensen, Hail, and Leuz (2013) and Naranjo, Saavedra, and Verdi (2016) and include European countries' IFRS mandates, in 2005, as well as mandates in other countries at different dates.

Log of the sum of imports and exports between the U.S. and the firm home country during the year according to the ComTrade, UN.

An indicator variable equal to one if the firm participates in a local market index according to Datastream.

Ratio of international sales to total sales according to Datastream.

Regression-based factor scores for the principal component factor analysis of the four investor communication variables (Corporate Access US, Conference Calls, Management Forecasts and Log of Press Releases).

Percentage change in total assets from year $\mathrm{t}$ to year $\mathrm{t}+1$.

Percentage change in earnings from year $t$ to year $t+1$.

Ratio of total liabilities over total assets.

Natural logarithm of total assets in U.S. dollars. 


\section{Variable Definitions (Continued)}

Variable Definition

Log Press Releases

Management Forecasts

News Content

Number of Analysts

Number of Institutions

Number of Media Articles

Proportion Corp.

Access Home vs U.S.

ROA

Sales Growth

Tobin's q

Turnover

Xlisted
Log of 1 plus the number of firm-initiated press releases disseminated by PR Newswire and Business Wire according to Factiva.

Number of initial forecasts disclosed by the firm during the year according to $\mathrm{I} / \mathrm{B} / \mathrm{E} / \mathrm{S}$ Guidance. Includes forecasts of earnings, EBITDA, sales, dividends, CAPEX and margins for all horizons.

Average composite sentiment (CSS) of the firm-initiated press releases disclosed during the year according to RavenPack. Good news years are defined as firm-years with average CSS greater than 50. Bad news years are defined as firm-years with average CSS lesser or equal to 50. I define firminitiated press releases as the articles in RavenPack with a relevance score $>90$ and News Type equal to Press-Release. I order to avoid duplicates, I delete press releases disclosed less than 15 minutes apart.

Number of distinct analysts issuing a forecast for the firm during the year according to $\mathrm{I} / \mathrm{B} / \mathrm{E} / \mathrm{S}$.

Number of U.S. institutional investors according to Thomson-Reuters Institutional Holdings and Mutual Funds Databases using the last report of the year.

Number of media articles disclosed during the year according to RavenPack. I keep only articles with a relevance score $>90$ and news type equal to Full Article.

Corporate Access Home/(Corporate Access US + Corporate Access Home)

Ratio of net income before extraordinary items over total assets.

Growth rate in sales measured as sales in the current year minus sales in the prior year divided by sales in the prior year.

Market value of equity plus book value of liabilities divided by book value of assets.

Annual share turnover in the U.S. measured as the sum of the daily number of shares traded in the U.S. divided by the total shares outstanding.

Indicator variable equal to one if the firm is cross-listed in the U.S. Includes both exchange and OTC cross-listings. 


\section{BIBLIOGRAPHY}


Aggarwal, R., I. Erel, R. Stulz, and R. Williamson. 2009. Differences in governance practices between u.s. and foreign firms: measurement, causes, and consequences. Review of Financial Studies 22 (8): 3131-3169.

Baginski, S. P., and K. C. Rakow Jr. 2012. Management earnings forecast disclosure policy and the cost of equity capital. Review of Accounting Studies 17: 279-321.

Baker, H. K. 1992. Why U.S. companies list on the London, Frankfurt and Tokyo stock exchanges. Journal of International Securities Markets 6: 219-227.

Baker, H. K., J. R. Nofsinger, and D. G. Weaver. 2002. International cross-listing and visibility. Journal of Financial and Quantitative Analysis 37 (3): 495-521.

Bancel, F., and U.R. Mittoo. 2001. European managerial perceptions of the net benefits of foreign stock listings. European Financial Management: 213-236.

Beatty, A., S. Liao, and J. Yu. 2013. The spillover effect of fraudulent financial reporting on peer firms' investment efficiency. Journal of Accounting and Economics 55: 183-205.

Beiting, C., S. Srinivasan, and G. Yu. 2014. Securities litigation risk for foreign companies listed in the U.S. Harvard Business School Working Paper, No. 13-036.

Bohn, H., and L. L. Tesar. 1996. US equity investment in foreign markets: portfolio rebalancing or return chasing? American Economic Review 86 (2): 77-81.

Bradshaw, M. T., B. J. Bushee, and G. Miller. 2004. Accounting choice, home bias, and U.S. investment in non-U.S. firms. Journal of Accounting Research 42 (5): 795-841.

Brennan, M. J., and H. H. Cao. 1997. International portfolio investment flows. Journal of Finance 52 (5): $1851-80$.

Brochet, F., P. Naranjo, and G. Yu. 2016. The capital market consequences of language barriers in the conference calls of non-U.S. firms. The Accounting Review 91 (4): 1023-1049.

Bushee, B., M. Jung, and G. Miller. 2011. Conference presentations and the disclosure milieu. Journal of Accounting Research 49, 1163-1192.

Bushee, B., and G. Miller. 2012. Investor relations, firm visibility, and investor following. The Accounting Review 87 (3): 867-897.

Christensen, H., L. Hail, and C. Leuz. 2013. Mandatory IFRS reporting and changes in enforcement. Journal of Accounting and Economics 56: 147-177.

Claus, J. and J. Thomas. 2001. Equity premia as low as three percent? Evidence from analysts' earnings forecasts for domestic and international stock markets. Journal of Finance 56: $1629-1666$. 
Coffee Jr., J. 1999. The future as history: the prospects for global convergence in corporate governance and its implications. Northwestern Law Review 93: 641-707.

Coffee Jr., J. 2002. Racing towards the top?: the impact of cross-listings and stock market competition on international corporate governance. Columbia Law Review 102: 17571831.

Diamond, D., and R. Verrecchia. 1991. Disclosure, liquidity and the cost of equity capital. The Journal of Finance 46: 1325-1360.

Doidge, C., G. A. Karolyi, and R. Stulz. 2004. Why are foreign firms that are listed in the U.S. worth more? Journal of Financial Economics 71: 205-238.

Doidge, C., G. A. Karolyi, and R. Stulz. 2009. Has New York become less competitive than London in global markets? Evaluating foreign listing choices over time. Journal of Financial Economics 91: 253-277.

Domowitz, I., J. Glen, and A. Madhavan. 1998. International cross-listing and order flow migration: Evidence from an emerging market. Journal of Finance 53 (6): 2001-2027.

Durnev, A., and E. H. Kim. 2005. To steal or not to steal: firm attributes, legal environment, and valuation. The Journal of Finance 60(3): 1461-1493.

Easley, D., and M. O'Hara. 2004. Information and the cost of capital. The Journal of Finance 59: $1553-1583$.

Fanto, J. A., and R. S. Karmel. 1997. Report on the attitudes of foreign companies regarding a U.S. listing. Stanford Journal of Law, Business and Finance 51: 37-58.

Foerster, S., and G. A. Karolyi. 1998. Multimarket trading and liquidity: A transaction data analysis of Canada-US interlistings. Journal of International Financial Markets, Institutions and Money 8: 393-412.

Foerster, S., and G. A. Karolyi. 1999. The effects of market segmentation and investor recognition on asset prices: Evidence from foreign stocks listing in the U.S. Journal of Finance 54: 981-1014.

Francis, J., J. Hanna, and D. Philbrick. 1997. Management communications with securities analysts. Journal of Accounting and Economics 24: 363-394.

Gigler, F., and T. Hemmer. 1998. On the frequency, quality, and informational role of mandatory financial reports, Journal of Accounting Research 36 (Supplement): 117-147.

Giroud, X. 2013. Proximity and investment: Evidence from plant-level data. The Quarterly Journal of Economics 128 (2): 861-915. 
Glosten, L., and P. Milgrom. 1985. Bid, ask, and transaction prices in a specialist market with heterogeneously informed traders. Journal of Financial Economics 13: 71-100.

Gozzi, J. C., R. Levine, and S. L. Schmukler. 2008. Internationalization and the evolution of corporate valuation. Journal of Financial Economics 88: 607-632.

Green, T. C., R. Jame, S. Markov, and M. Subasi. 2014. Broker-hosted investor conferences. Journal of Accounting and Economics 58 (1): 142-166.

Halling, M., M. Pagano, and J. Zechner. 2008. Where is the market? Evidence from cross-listings in the United States. The Review of Financial Studies 21 (2): 725-761.

Hail, L., and C. Leuz. 2009. Cost of capital effects and changes in growth expectations around U.S. cross listings. Journal of Financial Economics 93: 428-454.

Healy, P., A. Hutton, and K. Palepu. 1999. Stock performance and intermediation changes surrounding sustained increases in disclosure. Contemporary Accounting Research 16: 485-520.

Karolyi, G. A. 1998. Why do companies list shares abroad? A survey of the evidence and its managerial implications. Financial Markets, Institutions and Instruments 7: 1-60.

Karolyi, G. A. 2006. The world of cross-listings and cross-listings of the world: Challenging conventional wisdom. Review of Finance 10: 1-54.

Karolyi, G. A. 2012. Corporate governance, agency problems and international cross-listings: A defense of the bonding hypothesis. Emerging Markets Review 13 (4): 516-547.

Karolyi, G. A., and R. C. Liao. 2015. The economic consequences of investor relations: A global perspective. Working paper, Cornell University, Rutgers University.

Kim O., and R. E. Verrecchia. 1994. Market liquidity and volume around earnings announcements. Journal of Accounting and Economics 17: 41-67.

King, M. R., and D. Segal. 2009. The long-term effects of cross-listing, investor recognition, and ownership structure on valuation. Review of Financial Studies 22 (6): 2393-2421.

King, M. R., and U. R. Mittoo. 2007. What companies need to know about international crosslisting. Journal of Applied Corporate Finance 19 (4): 60-74.

Kirk, M., and J. Vincent. 2014. Professional investor relations within the firm. The Accounting Review 89 (4): 1421-1452.

Kirk, M., and S. Markov. 2016. Come on over: Analyst/investor days as a disclosure medium. The Accounting Review 91 (6): 1725-1750. 
Kyle, A. 1985. Continuous auctions and insider trade. Econometrica: 1315-35.

Lang, M. H., K. V. Lins, and D. P. Miller. 2003a. ADRs, analysts, and accuracy: Does cross listing in the United States improve a firm's information environment and increase market value? Journal of Accounting Research 41 (2): 317-345.

Lang, M. H., and R. Lundholm. 1993. Cross-sectional determinants of analyst ratings of corporate disclosures. Journal of Accounting Research 31: 246-271.

Lang, M. H., and R. Lundholm. 2000. Voluntary disclosure and equity offering: reducing information asymmetry or hyping the stock? Contemporary Accounting Research 17: 623-62.

Lang, M. H., J. S. Raedy, and M. H. Yetman. 2003b. How representative are firms that are crosslisted in the United States? An analysis of accounting quality. Journal of Accounting Research 41 (2): 363-386.

La Porta, R., F. Lopez-de-Silanes, A. Shleifer, and R. Vishny. 2000. Investor protection and corporate governance. Journal of Financial Economics 58: 3-27.

Lehavy, R., and R. Sloan. 2008. Investor recognition and stock returns. Review of Accounting Studies 13: 327-361.

Loughran, T., and J. R. Ritter. 1995. The new issues puzzle. The Journal of Finance 50: 23-51.

Lundholm, R., R. Rogo, and J. Zhang. 2014. Restoring the Tower of Babel: An analysis of text and numbers in management communications of U.S. and cross-listed firms. The Accounting Review 89 (4): 1453-1485.

Merton, R. C. 1987. A simple model of capital market equilibrium with incomplete information. Journal of Finance 42: 483-510.

Mittoo, U. R. 1992. Managerial perceptions of the net benefits of foreign listing: Canadian evidence. Journal of International Financial Management and Accounting 4: 40-62.

Mittoo, U. R. 2003. Globalization and the value of U.S. listings: Revisiting Canadian evidence. Journal of Banking and Finance 27: 1629-61.

Naranjo, P., D. Saavedra, and R. Verdi. 2016. Financial reporting regulation and financing decisions. Working paper, Rice University, UCLA, Massachusetts Institute of Technology.

Pulatkonak, M., and G. Sofianos. 1999. The distribution of global trading in NYSE-listed nonU.S. stocks. NYSE 99 (3).

Sarkissian, S., and M. J. Schill. 2009. Are there permanent valuation gains to overseas listing? The Review of Financial Studies 22: 371-412. 
Smith, K. and G. Sofianos. 1997. The impact of an NYSE listing on the global trading of non-U.S. stocks. NYSE 97 (2).

Shroff, N., A. Sun, H. White and W. Zhang. 2013. Voluntary disclosure and information asymmetry: evidence from the 2005 securities offering reform. Journal of Accounting Research 51: 1299-1345.

Shroff, N., R. S. Verdi, and G. Yu. 2014. Information environment and the investment decisions of multinational corporations. The Accounting Review 89 (2): 759-790.

Siegel, J. 2005. Can foreign firms bond themselves effectively by submitting to U.S. law? Journal of Financial Economics 75: 319-60.

Silva, A. C., and G. A. Chávez. 2008. Cross-listing and liquidity in emerging market stocks. Journal of Banking and Finance 32: 420-433.

Stulz, R. M. 1999. Globalization, corporate finance, and the cost of capital. Journal of Applied Corporate Finance 26:3-28. 